NBER WORKING PAPER SERIES

DIFFERENCES IN GOVERNANCE PRACTICES BETWEEN U.S. AND FOREIGN FIRMS:
MEASUREMENT, CAUSES, AND CONSEQUENCES

\author{
Reena Aggarwal \\ Isil Erel \\ René Stulz \\ Rohan Williamson \\ Working Paper 13288 \\ http://www.nber.org/papers/w13288 \\ NATIONAL BUREAU OF ECONOMIC RESEARCH \\ 1050 Massachusetts Avenue \\ Cambridge, MA 02138 \\ August 2007
}

We are grateful for comments from Marcus Caylor, Art Durnev, Mara Faccio, Allen Ferrell, Wayne Guay, David Hirshleifer, Jon Karpoff, Christo Karuna, Pedro Matos, Antoinette Schoar, Jérôme Taillard, Marc Weinstein, and Marc Zenner. We thank participants at seminars at Case Western Reserve University, McMaster University, MIT, Northeastern University, Queens University, the University of California at Irvine, the University of Iowa, the University of South Florida, and the University of Southern California, as well as participants at the NYSE/World Bank/University of Virginia Conference on Emerging Markets, the Wharton Conference on Corporate Governance and Globalization, and the 2007 Western Finance Association Meetings. We are grateful to Javier Ayala for research assistance. An earlier version of the paper was circulated under the title, "Do U.S. firms have the best corporate governance? A cross-country examination of the relation between corporate governance and shareholder wealth". The views expressed herein are those of the author(s) and do not necessarily reflect the views of the National Bureau of Economic Research.

(C) 2007 by Reena Aggarwal, Isil Erel, René Stulz, and Rohan Williamson. All rights reserved. Short sections of text, not to exceed two paragraphs, may be quoted without explicit permission provided that full credit, including $\odot$ notice, is given to the source. 
Differences in Governance Practices between U.S. and Foreign Firms: Measurement, Causes, and Consequences

Reena Aggarwal, Isil Erel, René Stulz, and Rohan Williamson

NBER Working Paper No. 13288

August 2007

JEL No. G30,G32,G34,G38,K22

\begin{abstract}
Using an index which increases as a firm adopts more governance attributes, we find that $12.7 \%$ of foreign firms have a higher index than matching U.S. firms. The best predictor for whether a foreign firm adopts more governance attributes than a comparable U.S. firm is whether the firm comes from a common law country. We show that the value of foreign firms is negatively related to the difference between their governance index and the index of matching U.S. firms. This relation is robust to various approaches to control for the endogeneity of corporate governance and is consistent with the hypothesis that foreign firms are valued less because country characteristics make it suboptimal for them to invest as much in governance as comparable U.S. firms. Overall, our evidence suggests that firm-level governance attributes are complementary to rather than substitutes for country-level investor protection, so that better country-level investor protection makes it optimal for firms to invest more in internal governance. Our evidence supports the view that minority shareholders of a typical foreign firm would benefit from an increase in investment in governance, but that the firm's controlling shareholder and possibly other stakeholders would not.
\end{abstract}

Reena Aggarwal

Georgetown University

Finance Group

McDonough School of Business

G 04, Old North

Washington, DC 20057

aggarwal@georgetown.edu

Isil Erel

Department of Finance

The Ohio State University

832 Fisher Hall

2100 Neil Avenue

Columbus, OH 43210

erel_1@cob.osu.edu
René Stulz

The Ohio State University

Fisher College of Business

806A Fisher Hall

2100 Neil Avenue

Columbus, $\mathrm{OH}$ 43210-1144

and NBER

stulz_1@cob.osu.edu

Rohan Williamson

Georgetown University

Finance Group

McDonough School of Business

G 04 Old North

Washington, DC 20057

WILLIARG@georgetown.edu 


\section{Differences in Governance Practices between U.S. and Foreign Firms: Measurement, Causes, and Consequences}

Using the well-known definition of Shleifer and Vishny (1997), governance consists of the mechanisms which insure that shareholders receive a return on their investment. Governance depends both on country-level as well as firm-level mechanisms. The country-level governance mechanisms include a country's laws, its culture and norms, and the institutions which enforce the laws. Firm-level or internal governance mechanisms are the mechanisms that operate within the firm. Firm-level governance mechanisms are costly, so that the adoption of internal governance mechanisms or attributes by a firm is an investment, and the payoffs from that investment differ across countries and across firms (see, e.g., Doidge, Karolyi and Stulz (2007), Fulghieri and Suominen (2006), John and Kedia (2006)).

The U.S. is recognized to have extremely high financial and economic development, to have strong investor protection, and to protect property rights well. On theoretical grounds, it is not clear whether the characteristics of the U.S. make firm-level investment in governance more or less advantageous for U.S. firms relative to firms from countries which do not have the same high level of development and investor protection as the U.S. One possibility is that foreign firms would invest less in firm-level governance if they were in the U.S. because firm-level governance and country-level investor protection are substitutes. An alternative possibility is that investment in firm-level governance is less productive in countries with poor economic development and weak investor protection than it is in the U.S., so that firm-level governance and investor protection are complements. Though there is a considerable literature that compares the quality of institutions across countries, there is no systematic comparison of firm-level investment in governance between the U.S. and foreign countries and furthermore there is no investigation of whether differences in firm-level governance between foreign firms and comparable U.S. firms have implications for the valuation of foreign firms.

We find strong evidence that foreign firms invest less in governance than comparable U.S. firms, so that investment in firm-level governance is higher when a country becomes more economically and financially developed and better protects investor rights. Further, to the extent that institutional and 
development weaknesses reduce a foreign firm's investment in corporate governance compared to a U.S. firm, we would expect the value of the foreign firm to be lower. As expected, we find that the value of foreign firms measured by Tobin's $q$ is negatively related to the size of their governance investment shortfall relative to U.S. firms.

To conduct our investigation, we need information about firm-level corporate governance attributes for a large number of firms across a large number of countries. Further, we would like measures of individual governance attributes to be computed in the same way across all these firms. Two widely known governance rankings include both U.S. and foreign firms. One of these two rankings, the Standard and Poor's ranking, focuses on disclosure. The other one, produced by Institutional Shareholder Services (ISS), uses a comprehensive inventory of governance attributes. We use the ISS governance attributes in this paper. By doing so, we can analyze 44 common governance attributes for 2,234 non-U.S. firms and 5,296 U.S. firms covering 23 developed countries. To compare firm-level governance across the U.S. and foreign countries, we have to create our own index making sure that the governance attributes included are relevant both for U.S. firms and foreign firms. We call it the GOV Index. One can reasonably disagree both with the governance attributes ISS focuses on and with the index we compute. It is obviously true, as Jack and Suzy Welch argue, that “Good governance comes down to a lot more than a point system.”1 However, if the index were to convey no information, we would simply find that the index we use is not related to firm value.

The GOV index satisfies our requirement of providing a firm-level governance measure that is comparable across countries. To evaluate the governance a foreign firm would have if it were in the U.S., we use a propensity score matching method and show that foreign firms generally have a lower $G O V$ index than if they were U.S. firms. We define the governance gap to be the difference between the governance index of a foreign firm and the governance index of a comparable U.S. firm, so that a firm with a positive governance gap has a higher value of the $G O V$ index than its matching U.S. firm. Only

\footnotetext{
1 “A dangerous division of labor,” by Jack and Suzy Welch, Business Week, November 6, 2006. For an academic version of this argument, see Arcot and Bruno (2006).
} 
$12.7 \%$ of foreign firms have a positive governance gap. Strikingly, $86.1 \%$ of these firms come from Canada and the U.K., so that firms from countries more similar to the U.S. are the ones that are the most likely to invest more in governance than comparable U.S. firms. Such a result is inconsistent with the hypothesis that investor protection and internal governance mechanisms are substitutes.

Having compared the governance of foreign and U.S. firms, we turn to the question of whether the governance gap helps explain a firm's valuation. It could be that the governance differences are unrelated to firm value because the governance attributes we focus on are not value relevant for foreign countries. Alternatively, the governance attributes we use might not capture the dimensions of governance that are important for shareholder wealth maximization. Our results are inconsistent with either of these hypotheses. We find that the value of foreign firms, measured by Tobin's $q$, increases as their GOV index shortfall relative to the index of matching U.S. firms falls.

A firm's governance is chosen by those who control the firm to maximize their welfare. Most foreign firms have a controlling shareholder (La Porta, Lopez-de-Silanes, and Shleifer, 1999), so that we focus on the decisions of controlling shareholders for simplicity. Since investments in corporate governance reduce the controlling shareholder's ability to extract private benefits from the firm, investments in corporate governance are more costly for the controlling shareholder than they are for minority shareholders. The controlling shareholder's choice of governance mechanisms depends on firm and country characteristics. He will find investments in governance more valuable if he expects the firm to have to raise funds externally because investments in governance reduce the cost of external capital. It follows that the controlling shareholder's choice of an optimal governance mechanism raises an endogeneity issue. High $q$ firms have greater investment opportunities and hence are more likely to raise external funds. As a result, high $q$ firms might invest more in governance, so that instead of having investments in governance increase $q$ it is possible that a higher $q$ would make the firm invest more in governance. Like other authors, we control for growth opportunities, but there could still be a relation between $q$ and governance because of other growth opportunities that we may fail to control for. To address this issue, we use two distinct approaches. First, we use an instrumental variable approach. With this approach, the negative 
relation between a foreign firm's governance index shortfall and its $q$ still holds. Second, we devise an experiment inspired by Rajan and Zingales (1998). If internal governance is more costly for foreign firms than for U.S. firms, we expect that the foreign firms comparable to the U.S. firms that benefit the most from investing in internal governance will find it optimal to invest less in governance than these U.S. firms because such investment is more expensive for them and they will suffer a loss of value as a result. We can therefore use regression analysis to investigate whether a foreign firm's $q$ is negatively related to the governance index value it would have in the U.S. We find that this is the case. Such a coefficient is not subject to an endogeneity bias because we are measuring the governance of a U.S. firm and the valuation of a foreign firm.

In addition to investigating the value relevance of differences in the governance index between foreign firms and comparable U.S. firms, we also consider the value relevance of specific governance provisions. We focus on provisions that have attracted considerable attention in the literature and among policymakers. We find that firms which do not have an independent board, an audit committee ratified annually, and an audit committee comprised solely of outsiders, have a lower value when their U.S. matching firm has these governance attributes. In contrast, neither board size nor separation of the chairman and CEO functions are value relevant.

Our paper contributes to a growing literature on the determinants and value relevance of firm-level governance attributes. This literature has been reviewed extensively (see, for instance, Becht, Bolton, and Roell (2003), and Denis and McConnell (2003)). A subset of this literature uses corporate governance indices as we do. In the U.S., authors have shown that firm value is related to indices of firm-level governance attributes (e.g., Gompers, Ishii, and Metrick (2003), Bebchuk and Cohen (2005), Bebchuk, Cohen, and Ferrell (2005)). Most importantly, from our perspective, Brown and Caylor (2006) show that the ISS index is value relevant in the U.S. and Aggarwal and Williamson (2006) demonstrate that changes in the index are associated with changes in firm value in the U.S. In an international setting, Durnev and Kim (2005) use the Credit Lyonnais Securities Asia (CLSA) corporate governance ratings and demonstrate that they are value relevant. The CLSA ratings cover 24 emerging countries and newly- 
emerging countries for 2000 and provide ratings for 494 companies. Francis, Khurana, and Pereira (2005) show that disclosure-related governance attributes measured by the Standard \& Poor's rankings affect firms' cost of capital across the world. Doidge, Karolyi, and Stulz (2007) show that country characteristics are important determinants of firm-level governance indices for firms outside the U.S. A couple of contemporaneous papers examine the relation between firm level governance provisions and firm value across countries using ISS data. Bruno and Claessens (2007) find that companies with strong corporate governance rely heavily on external finance. Chhaochharia and Laeven (2007) show that firms that adopt corporate governance provisions beyond those that are mandated by the country or corporate norms gain a positive valuation impact for their efforts. Though the results of many of these papers are complementary to the results of this paper, no paper compares the internal governance of foreign firms to the internal governance of comparable U.S. firms and derives the implications of that comparison for the value of these foreign firms.

The paper proceeds as follows. In Section II, we derive the hypotheses to be tested. In Section III, we describe the governance data used and the sample of firms. In Section IV, we show that on average firms in foreign countries invest less in governance than firms in the U.S. and investigate the determinants of this governance index shortfall. We report in Section $\mathrm{V}$ that firm value is positively related to the governance gap after controlling for firm characteristics and that the governance gap effect is not subsumed by other firm-level and country-level governance measures. In Section VI, we investigate how firms differ across the world in relation to specific governance attributes and show that these attributes are related to firm value. We report on the robustness of our results in Section VII and conclude in Section VIII.

\section{Firm value, country characteristics, and firm-level governance}

In this section, we first discuss the determinants of firm-level governance. We then draw implications for how firm-level governance differs across countries and how firm value is related to firm-level governance. 


\section{A. The determinants of firm-level governance}

In this paper, we follow a growing literature which uses a simple cardinal measure of internal governance, the number of governance attributes selected by a firm among a specified set of governance attributes. For most firms, the controlling shareholder chooses the firm's governance attributes to maximize his welfare rather than the welfare of the firm's minority shareholders. A controlling shareholder extracts private benefits from the firm. The extent to which a controlling shareholder can extract these benefits depends on the institutions in the firm's country as well as on the firm's choice of corporate governance attributes. By choosing more corporate governance attributes for the firm, the controlling shareholder reduces his ability to extract private benefits from the firm and therefore incurs private costs.

Better governance has a positive impact on the present value of the cash flows that accrue to minority shareholders for several reasons. First, since better governance reduces the controlling shareholder's private benefits, the minority shareholders receive a larger fraction of the cash flows generated by the firm. Second, better governance increases the proceeds from issuing equity, so that equity can be used to finance more investments. Third, to the extent that the discretion of the controlling shareholder to take actions that divert corporate assets is more limited as the firm adopts more corporate governance attributes, the cost of debt may also fall for the firm. Finally, it is more likely that firm decisions will be made to maximize shareholder wealth.

Though adopting better governance has benefits for the minority shareholders, the adoption of governance attributes imposes costs on them as well. First, these costs include out-of-pocket costs resulting from the adoption of governance attributes. For instance, it is costly to change a firm's charter, to use external auditors, or to have outside directors. Second, a firm may have to incur expenses to ensure that its adoption of governance attributes is credible. Third, the adoption of governance attributes may limit the flexibility of management.

The costs and benefits for minority shareholders resulting from the adoption of governance attributes depend both on firm and on country characteristics. In particular, investing more in governance will be 
more valuable for firms that require more external funding and less valuable for firms which have more assets that could be used for the benefit of controlling shareholders at the expense of minority shareholders. Therefore, we expect firms with better growth opportunities and fewer fixed assets to invest more in governance. The benefits of investing in governance decrease and the costs increase as a country's institutions are weaker and its economic and financial development lower. With better financial development, access to external finance is cheaper. Further, with good institutions, governance measures are more likely to be credible and commitments by the firm are more likely to be enforceable by minority shareholders. Finally, with poor economic development, it is more expensive to find individuals with the skills and training required to perform functions (such as high quality auditing) which are essential for good internal governance.

We denote by $B_{i j}\left(G O V_{i j}, H_{j}, F_{i}\right)$ the net benefit of the adoption of governance attributes for shareholders reflected in the firm's share price. This benefit falls as the costs of adopting governance attributes increases. We assume that this net benefit is an increasing concave function of $G O V_{i j}$ and depends on the firm's and on the country's characteristics. The adoption of more attributes reduces the value of the private benefits extracted by the controlling shareholder of the firm. We denote the controlling shareholder's private cost of investing in governance attributes by $P C_{i j}\left(G O V_{i j}, H_{j}, F_{i}\right)$. For simplicity, we assume that the only benefit the controlling shareholder receives from more governance attributes is through the value of his stake in the firm. We assume that $P C_{i j}\left(G O V_{i j}, H_{j}, F_{i}\right)$ is an increasing convex function of $G O V_{i j}$, so that the private cost of adopting governance attributes for the controlling shareholder is an increasing convex function of the number of attributes adopted.

The controlling shareholder maximizes his own welfare and chooses the firm's investment in governance, i.e., the firm's choice of $G O V_{i j}$, accordingly. With our notation, the market value of the firm's shares is higher because of the adoption of governance attributes by $B_{i j}\left(G O V_{i j}, H_{j}\right.$, $\left.F_{i}\right)$. If the controlling shareholder holds a fraction $\alpha_{i j}$ of the firm's shares, his net benefit from investing in governance, $S C_{i j}$, is the contribution of the firm's investment in internal governance to the value of his shares in the firm, $\alpha_{i j} B_{i j}\left(G O V_{i j}, H_{j}, F_{i}\right)$, minus his private cost from the firm's investment in internal 
governance, $P C_{i j}\left(G O V_{i j}, H_{j}, F_{i}\right)$. The controlling shareholder's gain from the firm's investment in governance is less than what it would be if he were a minority shareholder with the same stake because he bears private costs from that investment. The controlling shareholder chooses $G O V_{i j}$ to maximize $S C_{i j}$. With our assumptions, $S C_{i j}$ is a concave function of $G O V_{i j}$, so that there is a unique value of the governance index which maximizes the contribution of internal governance to firm value. With our assumptions, the optimal value of $G O V_{i j}$ solves the following equation:

$$
\alpha_{\mathrm{ij}} \frac{\partial \mathrm{B}_{\mathrm{ij}}\left(\mathrm{GOV}_{\mathrm{ij}}, \mathrm{H}_{\mathrm{j}}, \mathrm{F}_{\mathrm{ij}}\right)}{\partial \mathrm{GOV} V_{\mathrm{ij}}}=\frac{\partial \mathrm{PC}_{\mathrm{ij}}\left(\mathrm{GOV}_{\mathrm{ij}}, \mathrm{H}_{\mathrm{j}}, \mathrm{F}_{\mathrm{ij}}\right)}{\partial \mathrm{GOV} V_{\mathrm{ij}}}
$$

Figure 1 shows the intersection of the marginal benefit curve (the left-hand side of the equation) and marginal private cost curve (the right-hand side of the equation) which determines the controlling shareholder's choice $G O V_{i j}$. It necessarily follows from Figure 1 that the controlling shareholder's private cost of adopting governance attributes reduces the firm's investment in governance.

\section{B. Cross-country implications}

We now consider the cross-country implications of our analysis of the determinants of internal governance for both the level of internal governance and also for the relation between firm value and internal governance.

It is reasonable to view the U.S. as a country in which private benefits of control are smaller than in most countries. If lower private benefits of control simply shift the marginal cost function of governance attributes to the right in Figure 1, then everything else equal, our analysis predicts that $G O V$ is higher in countries with lower private benefits of control. To the extent that the private benefits of control are low in the U.S., we would expect U.S. firms to have a higher value for $G O V$ than comparable firms elsewhere. However, the minority shareholders' net benefit from investment in governance could be lower or higher in the U.S. than elsewhere. Presumably, the fact that private benefits are low in the U.S. reduces the gain for shareholders from investing in governance since governance investments reduce private benefits less 
than they would in countries in which private benefits are high, but at the same time, the fact that the U.S. is highly developed with good institutions may also mean that investments in governance are more productive.

In Figure 1, an improvement in investor protection has two effects. First, it shifts the marginal private cost curve of the controlling shareholder to the right because his ability to extract private benefits from the firm is lowered. This effect necessarily increases the firm's investment in internal governance. Second, an improvement in investor protection shifts the net marginal benefit curve to the right if internal governance and investor protection are complements and to the left if they are substitutes. Consider first the case where internal governance and investor protection are complements. In this case, it follows that an improvement in investor protection increases $G O V$ as well as increases the contribution to firm value of internal governance. Hence, in this case, we expect that firm value is positively related to $G O V$. We consider next the case where internal governance and investor protection are substitutes. In this case, the net benefit curve moves to the left as investor protection increases, so that $G O V$ may increase or fall as investor protection increases, but the contribution to firm value of internal governance necessarily falls. As a result, if investor protection and internal governance are substitutes, firm value and $G O V$ may be negatively related in the cross-section. Such an outcome would occur if $G O V$ increases as investor protection improves but internal governance and investor protection are substitutes.

Following Doidge, Karolyi, and Stulz (2007), we would expect that greater financial and economic development increases the benefits of investing in internal governance because it reduces the cost of external finance. Additionally, it decreases the costs of investing in internal governance by reducing the costs of the inputs to investment in internal governance. In Figure 1, economic and financial development shift the net benefit curve to the right, increase $G O V$, and increase the contribution of internal governance to firm value. 


\section{Firm-level governance attributes and the governance index}

In this section, we first describe the sample of firms covered by ISS. We then summarize the governance attributes used in our study and show how we aggregate these attributes to form an index.

\section{A. Sample firms}

ISS started providing the Corporate Governance Quotient (CGQ) for U.S. companies in 2002 and for international companies in 2003. The CGQ rankings are a relative measure of a firm's investment in internal governance, i.e., its adoption of governance attributes, and indicate the firm's investment in governance relative to firms in its industry or within an index in which the firm is included. To compute these indices (which we do not use in this paper), ISS collects information on governance attributes for a large number of U.S. and foreign companies. The information on governance attributes collected by ISS forms the raw material of this study.

The international coverage includes non-U.S. firms that are part of the following indices: 1) the MSCI EAFE index which covers 1,000 stocks in 21 developed countries outside North America and captures $85 \%$ of the total market capitalization for these countries; 2) the FTSE All Share Index which consists of the FTSE 100, FTSE 250 and FTSE SmallCap indices and captures 98\% of the U.K. market; 3) the FTSE All World Developed index which includes the largest firms in the developed markets; and 4) the S\&P/TSX index which represents $71 \%$ of the market capitalization of the Toronto Stock Exchange. There is considerable overlap among the indices. In this paper, we focus exclusively on the 2005 sample because it includes more firms and has fewer missing attributes for individual firms than the earlier samples. There are 2,234 foreign firms in our sample. The three countries with the largest number of firms covered are Japan (589), U.K. (530) and Canada (168). The three countries with the smallest number of firms covered are Portugal (14), Ireland (16) and New Zealand (18).

The U.S. coverage was substantially expanded in 2003. Firms are covered if they are included in any of the following indexes: the Standard and Poor's 500 index, the Standard and Poor's SmallCap 600 index, and the Russell 3000 index. The Russell 3000 index captures 98\% of the market capitalization of 
the U.S. markets. In addition, a number of firms are covered as long as they file on EDGAR. ISS excludes firms that have not filed a proxy in the last 18 months. In order to be included, a company has to both be a U.S. company and also be incorporated in a U.S. state. This means that companies like Tyco and Ingersoll-Rand that are part of the S\&P 500 are not included because they are incorporated in Bermuda. 5,296 U.S. companies are covered in 2005. The U.S. sample is described in greater detail in Aggarwal and Williamson (2006).

\section{B. Governance attributes}

ISS compiles 64 governance attributes for each U.S. firm and 55 attributes for foreign firms. How a firm fares for each attribute is determined by an examination of the firm's regulatory filings, annual reports, and website. Firms do not pay to get rated but can access their ratings and check for accuracy. Firms can only change their ratings by making and publicly disclosing changes to their governance structure. For each attribute, ISS evaluates whether a firm meets a threshold level of implementation of the attribute and considers that the firm has that attribute if it meets the threshold. We exclude 11 of the 55 foreign firm attributes from our analysis because either none of the firms satisfied minimally accepted criteria for these attributes or ISS replaced them with some other attributes for the U.S. sample in 2005. We use 44 attributes that are common for both U.S. and foreign firms.

The 44 attributes we select cover four broad sub-categories: 1) Board (25 attributes), 2) Audit (three attributes), 3) Anti-takeover (six attributes), and 4) Compensation and Ownership (10 attributes). Board attributes attempt to capture the aspects of the functioning of the board of directors that relate to board independence, composition of committees, size, transparency, and how work is conducted; Audit includes questions regarding the independence of the audit committee and the role of auditors; Anti-takeover provisions are from the firm's charter and bylaws and refer to dual-class structure, role of shareholders, poison pill and blank check preferred; and Compensation and Ownership deals with executive and director compensation issues related to options, stock ownership and loans, and how these types of compensation are determined and monitored. 
Table 1 provides a description of the threshold used by ISS for each of the 44 governance attributes for the full sample of non-U.S. firms for a firm to have an acceptable level of governance for that attribute. The governance attributes are arranged by sub-categories. There are several minimally accepted standards that are met by most firms. For example, seven of the 25 board-related criteria are met by more than 80 percent of the non-U.S. firms in our sample. These standards include: the CEO serves on the board of two or fewer companies, board size is greater than five but less than 16, the CEO is not listed as having a related-party transaction, the chairman and the CEO are separated or there is a lead director, shareholders vote on directors selected to fill vacancies, the board typically cannot amend bylaws without shareholder approval, and the board does not ignore shareholder proposals. For the three audit-related attributes, 83.9\% of the firms in our sample pay consulting fees to auditors that are lower than audit fees; for $35.3 \%$ of the firms the audit committee is comprised solely of independent directors; and for $58.4 \%$ of the firms auditors are ratified at the most recent meeting.

More than $90 \%$ of the firms meet four of the six anti-takeover provisions: a single class of common stock, shareholders can call special meetings, and the company either has no poison pill or has a poison pill that was approved by shareholders, the company is not authorized to issue blank check preferred. Only $7 \%$ of the firms require a simple majority to approve mergers implying that the remaining $93 \%$ of firms require a supermajority. Shareholders can act by written consent in $11.5 \%$ of our sample firms. More than half the firms meet four of the ten attributes related to compensation and ownership: no interlocks among compensation committee members (98.9\%), all stock-incentive plans adopted with shareholder approval (92.8\%), all directors with more than one year of service own stock (55.4\%), and repricing is prohibited (54\%).

\section{C. Corporate governance index construction}

We use the 44 individual attributes to create our $G O V$ index for each company. The index assigns a value of one to a governance attribute if the company meets the threshold level for that standard and zero otherwise. In contrast to prior studies in the literature, our index is computed for U.S. firms and foreign 
firms using the same criteria. It is common in the literature to use additive indices (e.g., Gompers, Ishii, and Metrick (2003), Bebchuk, Cohen and Ferrell (2004), Bebchuk and Cohen (2005)). Brown and Caylor (2006) use this approach to construct a governance index based on ISS governance attributes for the U.S. We express our index as a percentage. If a firm satisfies all 44 governance attributes, its $G O V$ index would equal $100 \%$. If an attribute is missing, the attribute is eliminated and the value of the index represents the percentage of non-missing attributes that the firm satisfies.

We also consider the individual governance attributes that have received the most attention in the academic literature and from observers. Admittedly, these attributes are arbitrary, but we include Board Independence: board is controlled by more than 50\% independent outside directors; Board Size: the board has more than five members but less than 16; Chairman/CEO Separation: chairman and CEO are separated or there is a lead director; Board Structure: annually elected board (no staggered board); Audit Committee Independence: audit committee comprised solely of independent outsiders; Auditor Ratification: auditors ratified at most recent annual meeting; and Stock Classes: only one class of common stock (no dual class).

\section{Cross-country comparisons of firm-level governance}

We first describe the sample of firms for which the firm-level governance attributes are available. We then investigate how investment in governance differs across countries focusing on a comparison between the U.S. and foreign firms.

\section{A. Characteristics of sample firms}

Table 2 provides descriptive statistics (medians) on a number of firm-specific variables by country including market capitalization (Mkt. Cap.) in millions of U.S. dollars, total assets (Assets) in millions of U.S. dollars, whether a firm is cross-listed in the U.S. (ADR is a dummy variable that takes a value of one if the firm is cross-listed in the U.S.), and Tobin's $q$. Tobin's $q$ is defined as ((total assets + market value of equity - total common equity - deferred taxes)/ total assets). All foreign firm-level data are obtained 
from Worldscope and Datastream, while U.S. firm-level data is from Compustat. We use stock prices at the end of 2004 and 2004 accounting data, taking the perspective that the governance attributes published by ISS in 2005 were in effect in 2004.

The median market capitalization and total assets are \$1,767 million and \$2,561 million respectively for the non-U.S. sample. There is considerable variation in the size of the firms in a country based on these two size proxies. Firms in Greece, New Zealand, the U.K., and the U.S. tend to be the smallest. However, U.K. and U.S. have low median size values because the coverage for these two countries is much broader and, therefore, captures a much more diverse set of firms compared to other countries where mostly large firms are covered. On average, French and Swedish firms are the largest based on market capitalization; French and Italian firms are the largest based on total assets. The median $q$ for the non-U.S. sample ranges from a low of 1.10 for Italy to a high of 1.49 for both Norway and Sweden and 1.51 for U.K. The U.S. has the largest median $q$ at 1.52. In our sample, more than half the firms from Austria, Canada and Ireland are cross-listed. Our sample covers more than $70 \%$ of the Worldscope market capitalization for all countries except Hong Kong (60\%) and the Netherlands (52\%).

\section{B. Differences in investment in governance across countries: Comparison of country averages}

The average values of $G O V$ for non-U.S. firms and for U.S. firms are 50\% and 59\%, respectively, as seen in Table 3. Figure 2 and Table 3 show that Canada (68\%), the U.S. (59\%), Finland (56\%), Switzerland (55\%) and the U.K. (55\%) are the countries with the highest average governance index. Countries with the lowest average governance index are Belgium (39\%), Portugal (39\%), Italy (41\%) and Norway (41\%). These results indicate that there is a wide degree of variation in the average value of $G O V$ across countries. Every country except Canada has a lower average index than the U.S. and the difference is statistically significant at the $1 \%$ level. 


\section{C. Differences in governance across countries: Comparison using matched pairs}

There is an obvious problem of interpretation when one compares country averages of the $G O V$ index: we are comparing governance for firms with different characteristics. As shown in Table 2, median firm size differs widely across countries. Differences in firm size can result from differences in countrylevel governance attributes. Perhaps more importantly, firm-level governance attributes have costs and benefits. If costs of governance attributes have a fixed component but benefits are proportional to firm size, one would expect larger firms to invest more in firm-level governance. In fact, in the U.S. there is a strong correlation between GOV and firm size measured by assets (approximately, 0.50). Consequently, by comparing $G O V$ across countries with different types of firms, we may be comparing apples to oranges.

To make our comparison of the governance of U.S. firms with the governance of foreign firms more precise, we match firms based on industry and closest propensity scores (p-scores). Drucker and Puri (2005) argue that this econometric method is superior because this matching employs fewer restrictions. Rosenbaum and Rubin (1983), Rubin (1997), and Conniffe, Gash, and O’Connell (2000), among others, have shown this approach to be more accurate. In order to implement this method, we calculate each firm's propensity score, which is simply equal to the probability that a firm with given characteristics is a foreign firm. This probability is calculated by using observable firm characteristics of both U.S. and nonU.S. firms, namely log of total assets (SIZE), two-year average sales growth (SGROWTH), two-year average research and development expense to sales (R\&D/SALES), cash to assets (CASH/ASSETS), capital expenditures to assets (CAPEX/ASSETS), property, plant and equipment to sales (PPE/SALES), earnings before interest and taxes to sales (EBIT/SALES), long-term debt plus short-term debt to assets (DEBT/ASSETS), as well as industry dummies, in a probit regression.

Of the 2,138 foreign firms that could be matched to U.S. counterparts based on industry and p-scores, 490 firms that operate in regulated industries (specifically, in Utilities, Transportation, Telecommunication Service, Insurance, Energy, and Banking) are excluded from the analysis. 
We define a firm's governance gap, $G O V G A P$, as the difference between its $G O V$ index value and the index value of its matching U.S. firm. Table 3 also shows the average difference between the $G O V$ index of foreign firms and their matching U.S. counterparts for the p-score matching method. It is immediately clear that matching has an impact on the size of the governance index difference. For instance, the only country with a positive difference with the U.S. when comparing averages is Canada. The difference in the index average between the U.S. and Canada drops from $9 \%$ to $6 \%$ when Canadian firms are matched with U.S. firms based on p-scores and industry. Further, when we match firms, the governance gap of foreign firms is worse than when we simply compare averages of the $G O V$ index across countries. Part of the reason is that the U.S. sample contains a large number of smaller firms and smaller firms typically have worse governance when measured by an index like $G O V$.

We also show in Table 3 the number of firms in each country that invest less in governance than their matching U.S. firm, the number of firms in each country that invest more in governance than their matching U.S. firm, and, finally, the percentage of firms in a country that invest more in governance than their matching U.S. firm based on the propensity score method. Across the world, $87.3 \%$ of firms invest less in governance than their matching U.S. firm. Strikingly, $86.1 \%$ of the firms that invest more in governance than their matching U.S. firm are in two countries, Canada and the U.K. Our sample has 22 non-U.S. countries. Only 15 countries have at least one firm that has better governance than its matching U.S. firm. There are only three countries with more than five firms that have a positive index gap: Canada, Finland, and the U.K. Canada is the country with the largest fraction of firms investing more in governance than their U.S. counterpart. It is the only country with a majority of firms with a positive gap, since Table 3 shows that $72.3 \%$ of the firms have a positive gap with the propensity score matching method. In the case of Finland, 29.2\% of the firms have a positive gap. Finally, for the U.K., the percentage is $24.4 \%$. Strikingly, two of the three countries with the largest percentage of firms with a positive gap are common law countries. 


\section{D. Firm and country characteristics and the GAP}

We saw in Section II that the governance gap, GOV GAP, defined as the difference between a firm's $G O V$ index value and the index value of its matching U.S. firm, depends on firm and country characteristics. We expect firms more likely to need access to external finance to have a lower gap. Also, we expect a firm's gap to be higher if its country is more economically and financially developed. Finally, depending on whether internal governance and investor protection are substitutes or complements, we expect the gap to be decreasing or increasing with investor protection.

For each firm, we measure its $G O V$ index and the $G O V$ index of its matching U.S. firm. Before we turn to the governance gap, it is useful to look at the relation between these two indices. If firm characteristics make it optimal for some firms to invest more in governance than others, we would expect a positive relation between a firm's $G O V$ index and the $G O V$ index of its U.S. matching firm. We find that this is the case. When we regress $G O V$ index on the $G O V$ index of the matching firm and a constant using country fixed effects, the $G O V$ index of the matching firm has a coefficient of 0.043 significant at the $10 \%$ level. The size of this coefficient is small. To the extent that country characteristics explain a large fraction of the variation in internal governance across non-U.S. countries as shown in Doidge, Karolyi, and Stulz (2007), a large coefficient would be surprising. However, we cannot exclude the concern that imperfections in matching lead to an attenuation bias.

Table 4 compares firm and country characteristics for firms with a positive governance gap versus firms with a negative governance gap. In this analysis, we require additional information in order to compute Tobin's $q$, which reduces the sample size slightly (only by 46 observations). The first two columns of Table 4 report the medians for the firms with a negative governance gap, i.e., firms that invest less in internal governance as measured by $G O V$ than their U.S. counterpart, and for the firms with a positive governance gap. Similar to previous work in the corporate governance literature (e.g., Gompers, Ishii, and Metrick (2003), Doidge, Karolyi, and Stulz (2004), and Durnev and Kim (2005)), we use Tobin's $q$ as the measure of firm value. It has the interpretation of the value created in excess of the cost of the assets. We find that the $q$ of firms which invest more in governance than their matching U.S. firms 
is significantly greater than the $q$ of firms which invest less. In the next section, we examine this valuation difference in greater detail.

The firms with a positive gap differ from those with a negative gap in many other ways besides having a higher $q$. In particular, the firms with a positive gap have a market capitalization and total assets that are smaller than the firms with worse governance. They also have greater sales growth, R\&D to sales, cash to assets, debt/assets, and closely-held ownership, but their capital expenditures are significantly lower.

We also investigate how country characteristics differ between firms with a positive gap and firms with a negative gap. The firms which invest more in governance than their U.S. counterparts come from countries with greater stock market capitalization to GDP, with common law, with a better judicial system, and with better laws and regulations to curb self-dealing by insiders. This result is completely inconsistent with the view that firm-level governance and country-level investor protection are substitutes and is supportive of the role of financial development (but not economic development) discussed in Section II. For comparison with Durnev and Kim (2005), we use the product of the index of rule of law and of the anti-director index of La Porta, Lopez-de-Silanes, Shleifer, and Vishny (1998) (as revised in Djankov, La Porta, Lopes-de-Silanes, and Shleifer (DLLS, 2006)) as a measure of the quality of the judicial system. We also use the anti self-dealing index from DLLS. Firms with a positive governance gap come from countries where these variables have higher values.

We report in Table 4 estimates of probit regressions in which the dependent variable takes a value of one if a foreign firm has better governance than its matching U.S. counterpart and equals zero otherwise. Few firm characteristics are systematically related to the probability that a firm has a positive governance gap. We find that firms with high $R \& D$ are more likely to have a positive gap and firms with high cash to assets ratio are less likely to have a positive governance gap. When we control for the anti-self-dealing index, we also find that larger firms are less likely to have positive governance gap. Not surprisingly, firms with greater sales growth are more likely to have a positive gap. We find that in these regressions the measures of investor protection are significant predictors of a firm's governance relative to its U.S. 
matching firm, so that firms in countries with higher investor protection are more likely to have a positive gap. By far, the most important variable in predicting whether a firm will have a positive GOV GAP is the common law dummy variable. Though we do not report the probit regression in a table, we find that adding common law to a regression without investor protection variables doubles the pseudo R-square of the regression. In other words, the legal origin of the country in which a firm is incorporated explains more than all other variables in the regression about whether the firm will invest more in governance than its matching U.S. firm.

We also investigate, but do not report, the determinants of the size of a firm's GOV GAP for firms that have a negative gap. We find that variables that make it more likely that a firm will have a positive governance gap reduce the size of the governance index shortfall for firms that have a shortfall.

\section{Firm value and internal governance}

We have now seen that the typical foreign firm invests less in governance than a comparable U.S. firm, but some foreign firms invest more than comparable U.S. firms. We show that firms that invest more in governance than their matching U.S. firm have higher value, in the sense that they have a higher Tobin's $q$, than the firms that invest less. In this section, we examine the relation between firm value and the index more deeply. We want to test the prediction in Section II that there should be a positive relation between $G O V$ and Tobin's $q$ in the cross-section given that we show in Section III that internal governance and investor protection are complements. Further, we would like to understand whether there is a linear relation between firm value and the governance gap, so that any increase in the governance gap is associated with a higher firm value. Alternatively, it could be that firm value falls as a firm's governance index shortfall relative to its U.S. matching firm increases, but that the value of a firm with a positive gap does not increase as the size of the gap increases. In this case, only a foreign firm's $G O V$ shortfall relative to the $G O V$ index of its matching firm would be value relevant.

A relation between firm value and the governance gap raises many questions. First, it could simply be that the governance index is correlated with observable firm characteristics that explain $q$ (firm 
characteristics omitted variable problem). To address this issue, we need to examine the relation between firm value and the governance gap controlling for firm characteristics. Second, it could be that each firm has optimal internal governance given its characteristics, so that a relation between firm value and the governance gap just indicates that variables which affect a firm's choice of internal governance also affect the firm's value (endogeneity problem). Third, if good investor protection and greater economic and financial development make greater investments in internal governance optimal, a relation between firm value and the governance gap could be due to the impact of these country characteristics on firm value rather than to a separate impact of internal governance on firm value (country characteristics omitted variable problem). We address the first two problems in the first sub-section and the third problem in the second sub-section.

\section{V.A. Firm value, the governance GAP, and firm characteristics}

In this section, we relate firm value to the governance gap. We use the governance index of the U.S. matching firm as a regressor. If the relation between $q$ and a firm's governance index is due to the firm characteristics that explain the governance index, we would expect much of that effect to be captured by the governance index of the U.S. matching firm. Tobin's $q$ can differ across firms because of industry and country characteristics rather than because of differences in firm characteristics. To account for industry and country sources of heterogeneity, we use industry and country fixed-effects. We employ an estimator that allows for clustering of the residuals at the country level.

Regression (1) of Table 5 shows estimates when we regress Tobin's $q$ on the governance index a firm would have if it were a U.S. firm, GOV_US, the governance index gap, GOV GAP, and firm size measured by the log of total assets, SIZE. The regression estimates show a strong positive relation between a firm's GOV GAP and its $q$. A firm's Tobin's $q$ is positively related to GOV_US, but the coefficient on $G O V_{-} U S$ is much larger than the coefficient on GOV GAP. Finally, $q$ is negatively related to firm size. 
To evaluate whether the relation to firm value depends on the sign of the GOV GAP, regression (2) separates $G O V G A P$ into a negative $G A P$ and a positive $G A P$. We find that the coefficient on negative $G A P$ is positive and significant at the $1 \%$ level. Consequently, firms with a greater index shortfall relative to their U.S. matching firm have lower value. In contrast, the coefficient on positive GAP is positive but insignificant.

In regression (1), GOV_US should capture the relation between governance and firm value if the firm were a U.S. firm. As a result, the significance of $G O V G A P$ has to be explained by the fact that the firm does not make the governance choices that a U.S. firm would make or because there is a matching error. If all firms choose $G O V$ optimally given firm characteristics and country characteristics do not matter, perfect matching would imply that GOV GAP is equal to zero for each firm since each firm would choose $G O V$ equal to the $G O V$ of the U.S. matching firm. Matching errors would imply that in some cases a foreign firm is matched with a U.S. firm that chooses optimally a higher $G O V$ index than the foreign firm because of differences in firm characteristics and in other cases it is matched with a U.S. firm that chooses a lower $G O V$ index. As a result, matching errors would be expected to lead to an average of GOV GAP close to zero. Since the average GOV GAP is significantly negative for all countries but Canada, it is implausible that matching mistakes explain the relation between GOV GAP and firm value.

In light of the endogeneity concerns which are endemic in the governance literature, a more plausible explanation for the relation between $q$ and $G O V$ GAP than matching errors is that we do not observe important firm-specific characteristics that affect the foreign firm's choice of governance as well as its $q .^{2}$ However, in our setting, such an explanation seems less likely than is typical in regressions that have $q$ as an explanatory variable. Since we control for a firm's governance if it were a U.S. firm, a relation between GOV GAP and $q$ induced by unobserved firm characteristics would have to result from systematic unobserved firm characteristics correlated with $q$ for foreign firms but not for U.S. firms. Such a systematic bias seems to stretch belief. Nevertheless, we address this endogeneity problem by instrumenting GOV GAP. A good instrument would be one that is uncorrelated with the unobserved firm

\footnotetext{
${ }^{2}$ See Hermalin and Weisbach (2003).
} 
characteristics which affect the firm's $G O V G A P$ but which has a highly significant regression coefficient in a regression of GOV GAP on the instrument, on GOV_US, and on size. ${ }^{3}$ We use as our instrument the average $G O V G A P$ of the other firms in the same industry and in the same country. ${ }^{4}$ Since we already control for the effect of industry on $q$ through industry fixed effects, there is no reason to believe that the instrument will be correlated with unobserved firm characteristics which affect the choice of internal governance. However, the regression used to test if the instrument is a useful instrument yields a t-statistic on the instrument in excess of 10, so that the instrument is useful. We reproduce regression (3) using the instrumental variable. The regression treats each country as a cluster but does not use country fixed effects since the instrumental variable is the intersection of an industry and a country. The coefficient on GOV GAP is close in value to the coefficient in the OLS regression and the coefficient is significant at the $10 \%$ level.

In regressions (1) to (3), we estimate the coefficient on GOV GAP controlling only for GOV_US and size. Having few variables in the second stage regressions makes it easier for the instrument to have a high $t$-statistic in the first stage regression, but it could be that the success of the instrumental variable regression is simply explained by the fact that GOV GAP proxies for firm characteristics. We also would expect firm characteristics to be related to $q$ directly rather than through the governance variables. In regression (4), we control for other firm characteristics generally used in the literature in $q$ regressions. We control for two-year average sales growth (SGROWTH), two-year average research and development expense to sales ( $R \& D / S A L E S)$, two-year average foreign sales to total sales (FOREIGN SALES/SALES), cash to assets (CASH/ASSETS), capital expenditures to assets (CAPEX/ASSETS), property, plant and equipment to sales (PPE/SALES), earnings before interest and taxes to sales (EBIT/SALES), and a measure of leverage corresponding to long-term debt and debt due in less than a year to assets (DEBT/ASSETS). Similar to prior work we winsorize extreme percentiles $\left(1^{\text {st }}\right.$ and $\left.99^{\text {th }}\right)$ of $q$, SGROWTH, R\&D/SALES, and FOREIGN SALES/SALES.

\footnotetext{
${ }^{3}$ See Wooldridge (2002), p. 84.

${ }^{4}$ For the use of a similar instrument in a different context, see John, Litov, and Yeung (2007).
} 
Regression (4) shows that adding these control variables does not affect the coefficient on GOV GAP, but it reduces the coefficient on GOV_US. The control variables have the signs one would generally expect based on the previous literature. In Regression (5), we split GOV GAP into a positive and a negative component. The values of the coefficients on the two components of GOV GAP are not meaningfully different from their values in Regression (2). It follows that the coefficient on GOV GAP as well as the coefficients on the positive and negative components of $G O V G A P$ are robust to controlling for firm characteristics. In Regression (6), we estimate Regression (4) instrumenting GOV GAP as we did in Regression (3). The coefficient on GOV GAP is positive and significant at the $10 \%$ level. Interestingly, the coefficient on GOV_US is no longer significant.

The evidence in this sub-section shows that there is a robust relation between GOV GAP and $q$ as well as a robust relation between negative $G A P$ and $q$. These relations hold when we control for the index value the foreign firm would have in the U.S. and for firm characteristics as well as when we allow for the endogenous determination of the foreign firm's governance. Our results are consistent with the hypothesis that foreign firms with a negative governance gap invest less in governance than would be required to maximize the wealth of their minority shareholders if they were U.S. firms, so that firm characteristics alone cannot explain these firms’ underinvestment in governance relative to U.S. firms.

\section{B. Country characteristics and the relation between firm value and GOV GAP}

We saw in Section II that, for firms with controlling shareholders, a foreign firm's internal governance is not chosen to maximize the wealth of minority shareholders but rather to maximize the welfare of the controlling shareholder. The ability of the controlling shareholder to extract private benefits is strongly determined by a country's investor protection, so that if investor protection is weaker, improvements in firm-level governance will be costlier for the controlling shareholder. Our evidence in Section IV showing that firms in countries with better investor protection are less likely to have a negative governance $G A P$ is consistent with this hypothesis. However, with this perspective, it could be that a country's institutions lead to an optimal firm ownership structure as well as an optimal firm-level 
governance regime. With this view, therefore, a firm in a given country with a given governance index would have the optimal governance index for that firm. It would follow that, even though the firm could increase its value for minority shareholders by choosing more governance attributes keeping ownership by the controlling shareholder unchanged, the firm does not really have this option because if it increases its investment in internal governance, it makes the controlling shareholder worse off and its existing ownership structure suboptimal. With this view, there would be an optimal level of $G O V$ that would be explained by country-level variables given the firm's other governance attributes. We explore the implications of this view in this sub-section.

We first address the issue that country characteristics are known to affect the use of other governance mechanisms. In particular, the literature shows that both insider ownership (see La Porta, Lopez-deSilanes, and Shleifer (1999) and Stulz (2005) for further references) and the adoption of ADR programs depend on country characteristics. Cross-listing enables a firm to have better governance by borrowing external governance attributes from the U.S. (e.g., Stulz (1999)). It is well-known that there is a positive relation between firm value and whether a firm has adopted an ADR program (Doidge, Karolyi, and Stulz (2004)). In regression (1) of Table 6, we therefore add these governance mechanisms to our regression (4) of Table 5 to make sure that internal governance has a distinct role to play. Adding these two additional governance measures has no impact on the coefficient of GOV GAP even though both measures have positive significant coefficients. In other words, internal governance as measured by our $G O V$ index has a distinct role in a corporation and does not proxy for the presence of other governance mechanisms. In Regression (2), we split GOV GAP into a positive and negative value. We find that the negative value has a positive significant coefficient, but the positive value does not.

To establish better the unique role of internal governance, we re-estimate the regression without $\mathrm{GOV}$ $G A P$. If firm fundamentals in a country with good investor protection make high investment in internal governance valuable for a firm, the same firm will be at a disadvantage in a country with poor investor protection in which such a high investment in internal governance is not optimal. Hence, we expect the value of firms that would have high governance in the U.S. to be lower abroad. We find that this is the 
case with Regression (3). Such a result is reminiscent of the result of Rajan and Zingales (1998) that industries which raise more external capital in the U.S. grow less in countries with poor financial development. In that paper, they use the amount of external capital raised in the U.S. as a benchmark for optimal external funding with good financial development and then show that industries that optimally would raise more external funding if their country were financially developed are at a disadvantage if their country is not as financially developed as the U.S. Here, we conduct a similar experiment. The results of this experiment are not subject to an endogeneity problem since we are using as our regressor the governance index of a different firm than the governance index of the firm whose $q$ we are measuring. Not surprisingly, the result only holds provided that we include all the control variables used in Regression (1). This is not surprising since, if we control for few firm characteristics, GOV_US proxies for firm characteristics that we know are positively related to $q$.

In the next regression, Regression (4), we add to Regression (1) a measure of economic development, GDP per capita, a measure of financial development, the stock market's capitalization divided by GDP, and a proxy for investor protection, a dummy variable that takes value one if a country is a common law country. These measures have been widely used in the literature. We see that none of the added variables has a significant coefficient. The coefficient on GOV GAP falls from 1.279 to 0.872 , but that fall is due to the removal of the country fixed effects rather than to the addition of development and investor protection variables. The significance of the GOV GAP coefficient falls as well, from the $1 \%$ level to the $5 \%$ level. Regression (5) shows, however, that the reason for the decrease in the coefficient on GOV GAP is the dramatic decrease in the coefficient on the positive component of GOV GAP. The coefficient on the negative component of GOV GAP is little affected by the change in regression specification, but the coefficient on the positive component of GOV GAP falls from 1.310 to 0.243 . In the next two regressions, we re-estimate Regression (5) using first the legal variable used by Durnev and Kim (2005), which is the product of the index of rule of law and of the anti-director index of La Porta, Lopez-de-Silanes, Shleifer, and Vishny (1998) (as revised in DLLS), instead of the common law dummy variable and then the antiself-dealing index of DLLS. We see that the same results hold, namely the coefficient on the negative 
component of GOV GAP remains large in absolute value and significant at the $1 \%$ level, but now the coefficient on the positive component of GOV GAP even becomes insignificantly negative.

Our regressions suggest that, when investor protection is good, there is no independent relation between internal governance mechanisms and firm value. However, investor protection fails to explain the relation between the negative governance gap and firm value. Our regressions do not support the hypothesis that there is an optimal level of internal governance determined by a country's level of investor protection alone after controlling for firm characteristics. All the results in this section suggest that firm value increases when a firm's governance index shortfall relative to its matching U.S. firm falls. The interpretation of this result is that firms are worth more when their controlling shareholders find it optimal to invest more in governance and that the amount they choose to invest in governance is not determined by their country's investor protection alone. This result is consistent with the hypothesis that how much controlling shareholders choose to invest in governance depends on their wealth and preferences as well as on firm and country characteristics. Our results do not imply that a greater investment in governance would make controlling shareholders better off, but they are consistent with the hypothesis that minority shareholders would be better off if firms with controlling shareholders were to invest more in corporate governance.

\section{Individual Governance Attributes}

So far, we have focused on the governance index and the relation between firm value and that index. When academics and other observers focus on corporate governance, they do not pay close attention to 44 attributes. Instead, they tend to focus on a handful of attributes that draw considerable attention. Therefore, we also consider individual governance attributes that we believe have received the most attention in the academic literature and from observers. Admittedly, the choice of these attributes is arbitrary. The seven attributes include, Board Independence: board is controlled by more than 50\% independent outside directors; Board Size: the board has more than five members but less than 16; Chairman/CEO Separation: chairman and CEO are separated or there is a lead director; Board Structure: 
annually elected board (no staggered board); Audit Committee Independence: audit committee comprised solely of independent outsiders; Auditor Ratification: auditors ratified at most recent annual meeting; and Stock Classes: only one class of common stock (no dual class).

We report in Table 7 the country averages for the seven governance attributes. We see in that table that U.S. firms rate highly on board independence and audit committee independence. In contrast, as expected, U.S. firms tend to rate poorly compared to most countries on the separation of the functions of the chairman of the board and of the CEO. Though most countries have a lower proportion of firms without a staggered board than the U.S., four countries (Canada, Denmark, Finland, and Sweden) have a much higher proportion of such firms than the U.S. More than half the countries have a higher proportion of firms than the U.S. meeting the minimum satisfactory threshold for board size. Finally, fifteen countries have a higher percentage of firms with one class of stock than the U.S.

Are these governance attributes related to firm value? Or, to put it differently and to use an example, are the foreign firms that separate the functions of chairman of the board and of CEO worth more? To examine this issue, we re-estimate the last regression of Table 5 in two different ways. First, we reestimate the regression substituting individual governance attributes for GOV. Second, we re-estimate the regression including all the individual governance attributes. As in Table 5, we use the governance attribute of the matching firm, the positive governance gap, and the negative governance gap.

Panel A of Table 8 shows the regression estimates when we introduce one individual attribute at a time. We see that separation of the functions of chairman of the board and CEO is not related to firm value. Neither are board size and stock classes. Board independence is significantly related to firm value. A firm whose board does not meet the board independence requirement is worth less when its matching U.S. firm meets that requirement. Our evidence is related to the evidence of Dahya, Dimitrov, and McConnell (2006). They find that board independence is positively related to firm value in the countries with poor investor protection when firms have a controlling shareholder. However, their sample includes 
less developed countries in contrast to ours. ${ }^{5}$ We find that board independence matters for developed countries. The strength of the board independence result is surprising in light of the U.S. evidence which fails to find a strong relation between board independence and firm value. ${ }^{6}$ Not having a staggered board when the matching U.S. firm has a staggered board is also associated with higher value. Bebchuk and Cohen (2005) document the costs associated with entrenched boards. We also find that audit committee independence is associated with higher value. Finally, not having annual audit ratification when the matching U.S. firm has it is costly, but having annual audit ratification when the matching U.S. firm does not does not lead to higher firm value. Panel B of Table 8 shows the estimates for the coefficients of the individual governance attributes when all the attributes are included as explanatory variables. The same coefficients are significant as in the regressions with the individual attributes.

\section{Alternative specifications}

In this Section, we investigate the robustness of the results presented so far. We present some of the results of that investigation in Table 9.

Our analysis has focused on comparing the governance of foreign firms to the governance of matching U.S. firms. An alternative approach would be to compare the governance/value relation for foreign and U.S. firms. In columns (1) and (2), we report regression (1) of Table 6 where GOV is the governance variable for foreign firms and the same regression without Closely-held, ADR, and Foreign Sales for U.S. firms. Since the regression controls for firm characteristics, the coefficient of $G O V$ is a measure of the value relevance of internal governance given firm characteristics. We see that the coefficient of $G O V$ is positive and significant in both regressions.

A concern is that only selected firms have a $G O V$ index. We investigate (but do not report regression estimates) whether the significance of the $G O V$ index could be accounted for by a selection bias. Using all firms for which data is available on Worldscope to estimate regression (1), we estimate a probit

\footnotetext{
${ }^{5}$ Our sample differs from theirs also because we do not limit firms to those with a controlling shareholder and because we have many more firms than they do.

${ }^{6}$ See Bhagat and Black (2002).
} 
regression for which the dependent variable is one if the firm has a $G O V$ index. The explanatory variables are a firm's asset size and its number of employees. Using Heckman's two-stage approach, we find that the $G O V$ index is still significant when we account for selection.

In regression (3), we use an index which adds up the seven governance attributes discussed in Section VI as our governance index. We call this index $\mathrm{GOV}_{7}$. We see that the coefficient on $\mathrm{GOV}_{7}$ is positive and significant, but smaller than the coefficient on $G O V$.

All the results discussed so far on the relation between internal governance and firm value used a specific propensity score model. In regression (4), we use an alternative matching approach which does not rely on the propensity score. For each foreign firm, we choose as a matching firm the U.S. firm in the same industry that has the closest amount of assets. We see that the results are similar to the results obtained when we use propensity matching. We also estimate different propensity score models but do not report the results in the table. In particular, the literature has used different measures of leverage when comparing firms across countries (see, for instance, Rajan and Zingales (1995)). Using different measures of leverage does not alter our conclusions. It is important to note, however, that the significance and magnitude of the coefficient on the positive governance gap in our $q$ regressions is sensitive to the matching procedure. In contrast, the significance and magnitude of the coefficient on the negative governance gap is robust across all our investigations. It follows that one should be cautious in making too much of the results that there is no positive relation between a positive governance gap and firm value.

A legitimate concern is whether our results depend on the inclusion of some countries with a large number of firms in our sample. In particular, the three countries with the largest number of firms, in descending order, are Japan, the U.K., and Canada. We estimate our regressions removing one of these countries at a time (in columns (5)-(7) of Table 9). It is immediately clear that removing one of these countries has no impact on our conclusions.

So far, our regressions have not controlled for a valuation benchmark. We would expect a firm to be worth more if it is in an industry that has a higher $q$. We add as an explanatory variable the median $q$ of 
the firm's industry globally in column (9). We find that our results are essentially the same with that added variable.

\section{Conclusion}

In this paper, we compare the governance of foreign firms to the governance of comparable U.S. firms using propensity scores. We find that it is quite important, when comparing the governance of foreign firms and U.S. firms, to do so by comparing apples to apples, namely firms with similar characteristics. Comparisons based on country averages of firm-level governance indices understate the magnitude of the differences in investment in internal governance across countries because small firms, which typically invest less in internal governance, are overweighted in the U.S. We call the difference in governance between a foreign firm and its matching U.S. firm the governance gap. For the typical foreign firm, the governance gap is negative in that the foreign firm invests less in internal governance than its matching U.S. firm. A foreign firm is much less likely to have a negative governance gap in a country with good investor protection, so that there is clear evidence that investment in internal governance and investor protection are complements rather than substitutes.

We find that the governance gap is strongly related to firm value. Firms which invest less in internal governance than their matching U.S. firm are worth less and their value shortfall increases with their internal governance investment shortfall. We conclude that a firm's underinvestment in governance compared to its matching U.S. firm cannot be explained by unobserved firm characteristics which would make it optimal for the foreign firm to invest less in internal governance. With our experimental design, an endogeneity explanation for our result based on firm characteristics would require a systematic bias in the ability of observed firm characteristics to explain internal governance and firm value in foreign countries compared to the U.S. In other words, foreign firms that invest less in internal governance than U.S. firms would have unobserved characteristics not present in their matching U.S. firms that make such a lower investment optimal. Such an explanation seems implausible. A more plausible explanation is that the underinvestment in governance is driven by country characteristics. 
Country characteristics therefore play an extremely important role in explaining why the typical foreign firm invests less in internal governance than its matching U.S. firm. Our results suggest that investor protection is a crucial determinant in the intensity of investment in internal governance, so that the ability of controlling shareholders to extract private benefits from firms plays a critical role in their evaluation of the benefits and costs of investments in internal governance. However, neither investor protection nor other country characteristics completely explain the relation between a firm's internal governance investment and its value. It could be that our proxies and regression specifications fail to identify the channel through which country characteristics exogenously lead to an optimal level of internal governance. However, more likely, firms typically underinvest in internal governance because doing so is optimal for their controlling shareholder and suboptimal for their minority shareholders. An increase in a typical foreign firm's investment in internal governance would make minority shareholders better off, but would not make its controlling shareholder better off. Further, in countries which place greater weight on the interests of stakeholders, an improvement in internal governance might also adversely affect these stakeholders. 


\section{References}

Aggarwal, Reena, and Rohan G. Williamson, 2006, Did new regulations target the relevant corporate governance attributes? Working Paper, Georgetown University.

Arcot, Sridhar R., and Valentina G. Bruno, 2006, One size does not fit all, after all: Evidence from corporate governance, Working Paper, London School of Economics.

Bebchuk, Lucian A., and Alma Cohen, 2005, The costs of entrenched boards, Journal of Financial Economics 78, 409-433.

Bebchuk, Lucian A., Alma Cohen, and Allen Ferrell, 2005, What matters in corporate governance? Working Paper, Harvard Law School.

Becht, Marco, Patrick Bolton and Ailsa Roëll, 2003, Corporate governance and control, in Handbook of the Economics of Finance, edited by George Constantinides, Milton Harris and René Stulz, NorthHolland.

Bhagat, Sanjay, and Bernard Black, 2002, The non-correlation between board independence and longterm firm performance, Journal of Corporation Law 27, 231-273.

Brown, Lawrence D., and Marcus L. Caylor, 2006, Corporate governance and firm valuation, Journal of Accounting and Public Policy July-Aug, 409-434.

Bruno, Valentina G. and Stijn Claessens, 2007, Corporate governance and regulation: Can there be too much of a good thing? Working Paper \#WPS 4140, World Bank Policy Research.

Chhaochharia, Vidhi and Luc Laeven, 2007, The invisible hand of corporate governance, Working Paper, International Monetary Fund.

Conniffe, Denis, Vanessa Gash, and Philip J. O’Connell, 2000, Evaluating state programmes: "Natural experiments” and propensity scores, The Economic and Social Review, 31, 283-308.

Dahya, Jay, Orlin Dimitrov, and John J. McConnell, 2006, Dominant shareholders, corporate boards and corporate value: A cross-country analysis, Journal of Financial Economics, forthcoming.

Denis, Diane, \& John J. McConnell, 2003. International corporate governance. Journal of Financial and Quantitative Analysis, 38, 1, 1-36.

Djankov, Simeon, Rafael La Porta, Florencio Lopez-de-Silanes, and Andrei Shleifer (DLLS), 2006, The law and economics of self-dealing, Working Paper, Harvard University.

Doidge, Craig, G. Andrew Karolyi, and René M. Stulz, 2004, Why foreign firms that list in the U.S. are worth more? Journal of Financial Economics 71, 205-238.

Doidge, Craig, G. Andrew Karolyi, and René M. Stulz, 2007, Why do countries matter so much for corporate governance? Journal of Financial Economics, forthcoming.

Drucker, Steven and Manju Puri, 2005, On the benefits of concurrent lending and underwriting, Journal of Finance, 60, 2763-2799. 
Durnev, Art, and E. Han Kim, 2005, To steal or not to steal: Firm attributes, legal environment, and valuation, Journal of Finance 60, 1461-1493.

Francis, Jere R., Inder K. Khurana, and Raynolde Pereira, 2005, Disclosure incentives and effects on cost of capital around the world, Accounting Review, 80, 1125-1162.

Fulghieri, Paolo, and Matti Suominen, 2006, Corporate governance, finance, and the real sector, Working Paper, University of North Carolina, Chapel Hill, NC.

Gilson, Ronald J., 2005, Controlling shareholders and corporate governance: Complicating the comparative taxonomy, ECGI-Law Working Paper No. 49/2005.

Gompers, Paul A., Joy L. Ishii, and Andrew Metrick, 2003, Corporate governance and equity prices, The Quarterly Journal of Economics, 118, 107-155.

Hansmann, Henry, and Reinier Kraakman, 2003, The end of history for corporate law, in J. Gordon and M. J. Roe eds.: Are Corporate Governance Systems Converging?, University of Chicago Press.

Hermalin, Benjamin E., and Michael S. Weisbach, 2003, Boards of Directors as an endogenously determined institution: A survey of the economic literature, Economic Policy Review 9, 7-26.

John, Kose, and Simi Kedia, 2006, Institutions, markets and growth: A theory of comparative corporate governance, unpublished working paper, New York University.

John, Kose, Lubomir Litov, and Bernard Yeung, 2007, Corporate governance and risk taking, Working Paper, New York University.

La Porta, R., F. Lopez-De-Silanes, and A. Shleifer, 1999, Corporate ownership around the world, Journal of Finance 54, 471-517.

La Porta, Rafael, Florencio Lopez-de-Silanes, Andrei Shleifer, and Robert Vishny (LLSV), 1998, Law and finance, Journal of Political Economy 106, 1113-1155.

Rajan, Raghuram G. and Luigi Zingales, 1995, What do we know about capital structure? Some evidence from international data, Journal of Finance 50, 1421-1460.

Rajan, Raghuram G. and Luigi Zingales, 1998, Financial dependence and growth, American Economic Review 88, 559-586.

Rosenbaum, Paul, and Donald Rubin, 1983, The central role of the propensity score in observational studies for causal effects, Biometrika 70, 41-55.

Rubin, Donald, 1997, Estimating causal effects from large data sets using propensity scores, Annals of Internal Medicine 127, 757-763.

Scott, Hal S., and George S. Dallas, 2006, Mandating corporate behavior: Can one set of rules fit all? Working Paper, Standard and Poor's.

Shleifer, Andrei, and Robert Vishny, 1997, A survey of corporate governance, Journal of Finance 52, 737-783. 
Stulz, René M., 1999, Globalization, corporate finance and cost of capital, Journal of Applied Corporate Finance 12, 8-25.

Stulz, René M., 2005, The limits of financial globalization, Journal of Finance 60, 1595-1638.

Wooldridge, Jeffrey M., 2002, Econometric analysis of cross section and panel data, MIT Press, Cambridge, MA. 
Figure 1

Determination of optimal value of GOV index

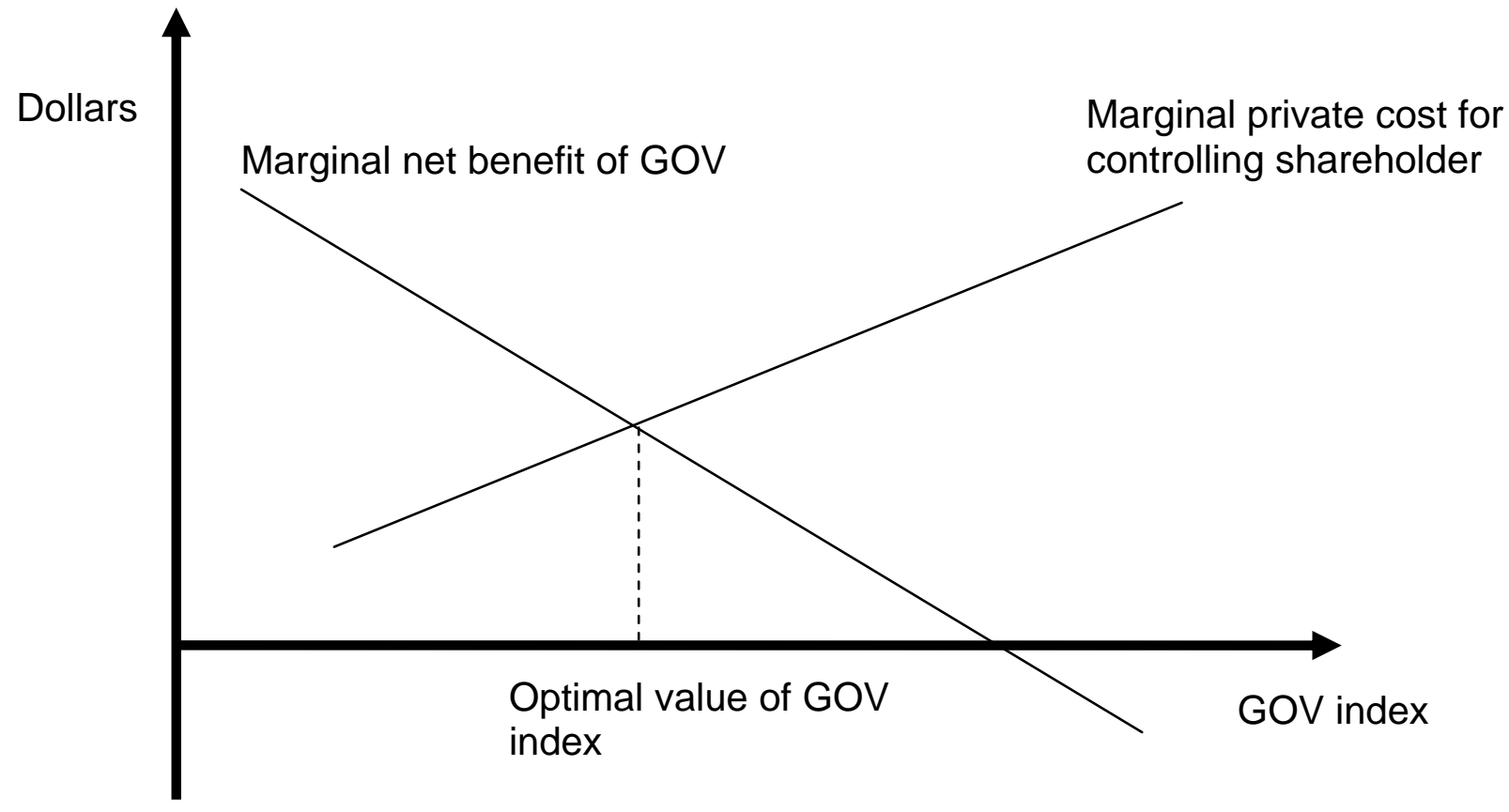


Figure 2

\section{Governance Scores by Country}

Values on the vertical axis represent the mean of the firm level governance index for a particular country. GOV is the percentage of 44 governance attributes that a firm meets based on the attributes that have nonmissing data. Mean governance scores are reported for each of the 23 countries as of 2005. The information is based on 1,714 non-U.S. firms and 4,070 U.S. firms from non-regulated industries.

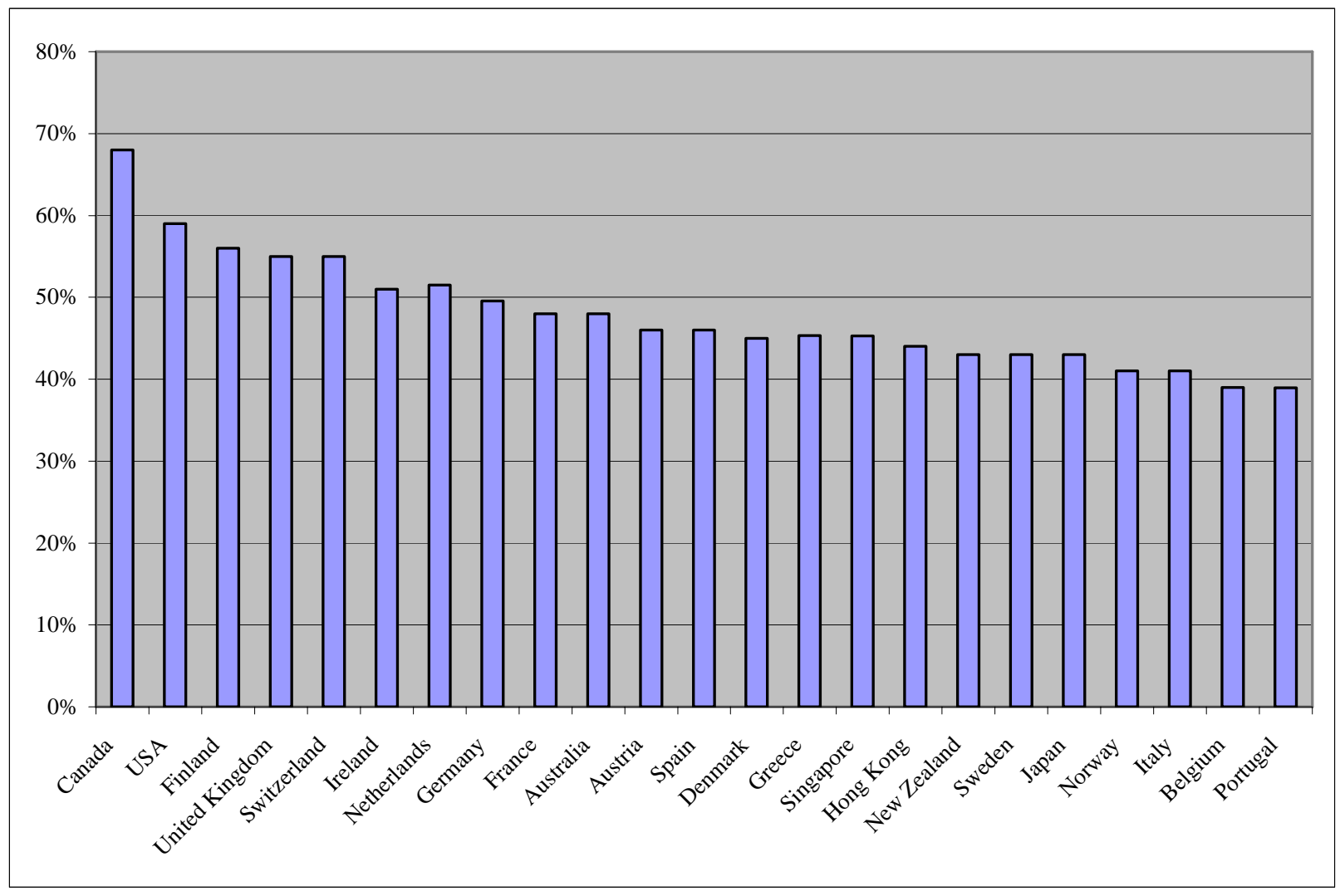


Table 1

Foreign Firms Satisfying Minimally Acceptable Governance Standards

The 44 governance attributes in the $\mathrm{GOV}_{44}$ index are divided into four sub-categories: Board, Audit, Anti-takeover, and Compensation \& Ownership. For each attribute we report the percentage of firms that satisfy the minimally acceptable governance standard in 2005. The sample consists of 2,234 foreign firms.

\begin{tabular}{|c|c|c|}
\hline & Minimally Acceptable Corporate Governance Standard & $\begin{array}{l}\text { \% of Foreign Firms } \\
\text { Meeting Criterion }\end{array}$ \\
\hline $\begin{array}{l}1 . \\
2 . \\
3 . \\
4 . \\
5 . \\
6 . \\
7 . \\
8 . \\
9 . \\
10 . \\
11 . \\
12 . \\
13 . \\
14 . \\
15 . \\
16 . \\
17 . \\
18 . \\
19 . \\
20 . \\
21 . \\
22 . \\
23 . \\
24 . \\
25 .\end{array}$ & $\begin{array}{l}\text { BOARD } \\
\text { All directors attended } 75 \% \text { of board meetings or had a valid excuse } \\
\text { CEO serves on the boards of two or fewer public companies } \\
\text { Board is controlled by more than } 50 \% \text { independent outside directors } \\
\text { Board size is at greater than five but less than } 16 \\
\text { CEO is not listed as having a related-party transaction } \\
\text { No former CEO on the board } \\
\text { Compensation committee comprised solely of independent outsiders } \\
\text { Chairman and CEO are separated or there is a lead director } \\
\text { Nominating committee comprised solely of independent outsiders } \\
\text { Governance committee exists and met in the past year } \\
\text { Shareholders vote on directors selected to fill vacancies } \\
\text { Governance guidelines are publicly disclosed } \\
\text { Annually elected board (no staggered board)* } \\
\text { Policy exists on outside directorships (four or fewer boards is the limit) } \\
\text { Shareholders have cumulative voting rights } \\
\text { Shareholder approval is required to increase/decrease board size } \\
\text { Majority vote requirement to amend charter/bylaws (not supermajority) } \\
\text { Board has the express authority to hire its own advisors } \\
\text { Performance of the board is reviewed regularly } \\
\text { Board approved succession plan in place for the CEO } \\
\text { Outside directors meet without CEO and disclose number of times met } \\
\text { Directors are required to submit resignation upon a change in job } \\
\text { Board cannot amend bylaws without shareholder approval or can only do } \\
\text { so under limited circumstances } \\
\text { Does not ignore shareholder proposal } \\
\text { Qualifies for proxy contest defenses combination points }\end{array}$ & $\begin{array}{c}77.8 \% \\
91.7 \% \\
32.6 \% \\
84.3 \% \\
93.5 \% \\
75.1 \% \\
28.9 \% \\
89.8 \% \\
15.8 \% \\
14.0 \% \\
83.5 \% \\
53.9 \% \\
24.9 \% \\
4.0 \% \\
1.6 \% \\
56.8 \% \\
3.5 \% \\
44.7 \% \\
44.7 \% \\
21.5 \% \\
10.1 \% \\
1.9 \% \\
\\
98.1 \% \\
100.0 \% \\
0.2 \%\end{array}$ \\
\hline $\begin{array}{l}26 . \\
27 . \\
28 .\end{array}$ & $\begin{array}{l}\text { AUDIT } \\
\text { Consulting fees paid to auditors are less than audit fees paid to auditors } \\
\text { Audit committee comprised solely of independent outsiders } \\
\text { Auditors ratified at most recent annual meeting }\end{array}$ & $\begin{array}{l}83.9 \% \\
35.3 \% \\
58.4 \%\end{array}$ \\
\hline & $\begin{array}{l}\text { ANTI-TAKEOVER } \\
\text { Single class, common } \\
\text { Majority vote requirement to approve mergers (not supermajority) } \\
\text { Shareholders may call special meetings } \\
\text { Shareholder may act by written consent } \\
\text { Company either has no poison pill or a pill that was shareholder approved } \\
\text { Company is not authorized to issue blank check preferred }\end{array}$ & $\begin{array}{c}93.2 \% \\
7.0 \% \\
99.7 \% \\
11.5 \% \\
98.6 \% \\
95.0 \%\end{array}$ \\
\hline
\end{tabular}




\begin{tabular}{|c|c|c|}
\hline & COMPENSATION \& OWNERSHIP & \\
\hline 35. & Directors are subject to stock ownership requirements & $12.2 \%$ \\
\hline 36. & Executives are subject to stock ownership guidelines & $15.0 \%$ \\
\hline 37. & No interlocks among compensation committee members & $98.9 \%$ \\
\hline 38. & Directors receive all or a portion of their fees in stock & $17.5 \%$ \\
\hline 39. & All stock-incentive plans adopted with shareholder approval & $92.8 \%$ \\
\hline 40. & Options grants align with company performance and reasonable burn rate & $78.5 \%$ \\
\hline 41. & Company expenses stock options & $42.6 \%$ \\
\hline 42. & All directors with more than one year of service own stock & $55.4 \%$ \\
\hline 43. & $\begin{array}{l}\text { Officers' and directors' stock ownership is at least } 1 \% \text { but not over } 30 \% \text { of } \\
\text { total shares outstanding }\end{array}$ & $28.1 \%$ \\
\hline & Repricing is prohibited & $54.0 \%$ \\
\hline
\end{tabular}


Table 2

\section{Descriptive Statistics}

The table provides descriptive statistics for each country. The first column, \# of firms, is the number of firms from each country that are in the sample in 2005. Median values are reported for market capitalization (Mkt. Cap.) and Assets in millions of U.S. dollars, and $q$ is Tobin's $q$ defined as ((total assets + market value of equity - total common equity - deferred taxes)/ total assets). \% ADR is the percentage of firms that are cross-listed. \% of WScope Mkt Cap is the percentage of the market capitalization of all firms in Worldscope for a country represented by our sample firms. The total row refers only to non-U.S. firms in the sample.

\begin{tabular}{lcccccc}
\hline Country & $\begin{array}{c}\text { \# of } \\
\text { firms }\end{array}$ & $\boldsymbol{Q}$ & Mkt. Cap. & Assets & \% ADR & $\begin{array}{c}\text { \% of WScope } \\
\text { Mkt Cap. }\end{array}$ \\
\hline Australia & 119 & 1.41 & 1,513 & 1,846 & $27 \%$ & $77 \%$ \\
Austria & 19 & 1.21 & 1,874 & 4,542 & $53 \%$ & $81 \%$ \\
Belgium & 25 & 1.16 & 2,831 & 4,010 & $16 \%$ & $80 \%$ \\
Canada & 168 & 1.38 & 1,864 & 2,443 & $64 \%$ & $77 \%$ \\
Denmark & 22 & 1.39 & 2,314 & 1,481 & $9 \%$ & $80 \%$ \\
Finland & 31 & 1.24 & 1,634 & 2,363 & $16 \%$ & $87 \%$ \\
France & 83 & 1.27 & 6,593 & 9,295 & $39 \%$ & $84 \%$ \\
Germany & 85 & 1.27 & 3,954 & 7,524 & $29 \%$ & $74 \%$ \\
Greece & 44 & 1.14 & 719 & 779 & $9 \%$ & $79 \%$ \\
Hong Kong & 110 & 1.28 & 1,780 & 2,497 & $45 \%$ & $60 \%$ \\
Ireland & 16 & 1.24 & 4,376 & 3,553 & $56 \%$ & $85 \%$ \\
Italy & 71 & 1.10 & 4,216 & 12,222 & $14 \%$ & $82 \%$ \\
Japan & 589 & 1.15 & 2,019 & 3,795 & $13 \%$ & $81 \%$ \\
Netherlands & 47 & 1.28 & 2,702 & 3,124 & $40 \%$ & $52 \%$ \\
New Zealand & 18 & 1.48 & 817 & 741 & $17 \%$ & $71 \%$ \\
Norway & 21 & 1.49 & 1,343 & 1,335 & $43 \%$ & $77 \%$ \\
Portugal & 14 & 1.13 & 3,400 & 5,168 & $29 \%$ & $86 \%$ \\
Singapore & 1.11 & 1,033 & 1,368 & $16 \%$ & $95 \%$ \\
Spain & 67 & 1.34 & 3,822 & 4,049 & $17 \%$ & $88 \%$ \\
Sweden & 54 & 4,461 & 4,293 & $21 \%$ & $85 \%$ \\
Switzerland & 43 & 1.49 & 3,253 & $28 \%$ & $89 \%$ \\
U.K. & 58 & 1.31 & 2,824 & 907 & $18 \%$ & $88 \%$ \\
U.S.A. & 1.51 & 690 & 386 & & $24 \%$ & \\
World excluding U.S.A. & 1.52 & 317 & 2,561 & & \\
\hline & 1.28 & 1,767 & & & \\
& 530 &, 296 & & & & \\
\end{tabular}


Table 3

Quality of Governance by Country and Relative to U.S.-Matched Firms

The governance score for a firm is the percentage of governance attributes for which the firm meets or exceeds the minimum satisfactory standard on the 44 ISS attributes (described in Table 1) for 2005. The sample consists of 1,714 non-U.S. firms (the number reduces to 1648 after p-score and industry matching) and 4,070 U.S. firms from non-regulated industries. The t-statistic measures the difference between the governance index for firms in a country relative to the U.S. Firms are compared using 1) country averages of sample firms and 2) averages with firms matched with propensity score (P-score) and industry affiliation. GOV Gap is the difference in the GOV score of the foreign firm and the U.S. matched firm and the average for all firms in a country is reported below. \# of Pos. Gap and \# of Neg. Gap represents the number of firms that are better/worse than the U.S. matched firm in terms of the quality of governance. The last column represents the percentage of firms in each country whose quality of governance is better that its U.S. match. *, **, *** reflects significance at the $10 \%, 5 \%$ and $1 \%$ levels.

\begin{tabular}{|c|c|c|c|c|c|c|c|c|}
\hline \multirow[b]{2}{*}{ Country } & \multicolumn{3}{|c|}{ Country Averages } & \multicolumn{5}{|c|}{ P-score and Industry Matching } \\
\hline & $G O V$ & GOV Gap & $t$-stat & GOV Gap & $t$-stat & \# of Neg. Gap & $\begin{array}{c}\text { \# of Pos. } \\
\text { Gap }\end{array}$ & $\begin{array}{c}\% \text { of Firms } \\
\text { with Pos. Gap }\end{array}$ \\
\hline Australia & $48 \%$ & $-11 \%$ & $-18.00 * * *$ & $-16 \%$ & $-16.13^{* * *}$ & 78 & 4 & $4.88 \%$ \\
\hline Austria & $46 \%$ & $-13 \%$ & $-18.41 * * *$ & $-18 \%$ & $-5.47 * * *$ & 9 & 0 & $0.00 \%$ \\
\hline Belgium & $39 \%$ & $-20 \%$ & $-11.40 * * *$ & $-27 \%$ & $-10.24 * * *$ & 18 & 1 & $5.26 \%$ \\
\hline Canada & $68 \%$ & $9 \%$ & $14.42^{* * *}$ & $6 \%$ & $6.34^{* * *}$ & 31 & 81 & $72.32 \%$ \\
\hline Denmark & $45 \%$ & $-14 \%$ & $-1.79 *$ & $-20 \%$ & $-5.11 * * *$ & 11 & 2 & $15.38 \%$ \\
\hline Finland & $56 \%$ & $-3 \%$ & $-7.73 * * *$ & $-5 \%$ & $-2.98 * * *$ & 17 & 7 & $29.17 \%$ \\
\hline France & $48 \%$ & $-11 \%$ & $-11.91^{* * *}$ & $-21 \%$ & $-17.36 * * *$ & 62 & 0 & $0.00 \%$ \\
\hline Germany & $50 \%$ & $-9 \%$ & $-15.92 * * *$ & $-18 \%$ & $-18.05^{* * *}$ & 62 & 2 & $3.13 \%$ \\
\hline Greece & $45 \%$ & $-14 \%$ & $-19.32 * * *$ & $-18 \%$ & $-7.32 * * *$ & 16 & 1 & $5.88 \%$ \\
\hline Hong Kong & $44 \%$ & $-15 \%$ & $-27.13^{* * *}$ & $-21 \%$ & $-17.50 * * *$ & 72 & 2 & $2.70 \%$ \\
\hline Ireland & $51 \%$ & $-8 \%$ & $-3.06^{* * *}$ & $-10 \%$ & $-3.16^{* * *}$ & 9 & 1 & $10.00 \%$ \\
\hline Italy & $41 \%$ & $-18 \%$ & $-25.88 * * *$ & $-27 \%$ & $-19.45^{* * *}$ & 38 & 0 & $0.00 \%$ \\
\hline Japan & $43 \%$ & $-16 \%$ & $-82.05^{* * *}$ & $-23 \%$ & $-59.64^{* * *}$ & 481 & 1 & $0.21 \%$ \\
\hline Netherlands & $51 \%$ & $-8 \%$ & $-6.19 * * *$ & $-16 \%$ & $-11.34^{* * *}$ & 38 & 2 & $5.00 \%$ \\
\hline New Zealand & $43 \%$ & $-16 \%$ & $-9.79 * * *$ & $-18 \%$ & $-5.90 * * *$ & 11 & 1 & $8.33 \%$ \\
\hline Norway & $41 \%$ & $-18 \%$ & $-13.64 * * *$ & $-24 \%$ & $-10.81^{* * *}$ & 13 & 0 & $0.00 \%$ \\
\hline Portugal & $39 \%$ & $-20 \%$ & $-13.50 * * *$ & $-26 \%$ & $-9.36^{* * *}$ & 7 & 0 & $0.00 \%$ \\
\hline Singapore & $45 \%$ & $-14 \%$ & $-17.74 * * *$ & $-21 \%$ & $-12.51^{* * *}$ & 46 & 2 & $4.17 \%$ \\
\hline Spain & $46 \%$ & $-13 \%$ & $-13.28 * * *$ & $-17 \%$ & $-10.80 * * *$ & 33 & 0 & $0.00 \%$ \\
\hline Sweden & $43 \%$ & $-16 \%$ & $-17.25 * * *$ & $-21 \%$ & $-12.00^{* * *}$ & 34 & 0 & $0.00 \%$ \\
\hline Switzerland & $55 \%$ & $-4 \%$ & $-3.56^{* * *}$ & $-11 \%$ & $-7.49 * * *$ & 43 & 3 & $6.52 \%$ \\
\hline U.K. & $55 \%$ & $-4 \%$ & $-10.79 * * *$ & $-7 \%$ & $-13.37 * * *$ & 307 & 99 & $24.38 \%$ \\
\hline U.S. & $59 \%$ & & & & & & & \\
\hline Total (w/o U.S.) & $50 \%$ & $-9 \%$ & & $-15 \%$ & $-47.82 * * *$ & 1436 & 209 & $12.68 \%$ \\
\hline
\end{tabular}


Table 4

\section{Comparison of Firms with Better Governance than U.S. Matching Firms}

The reported median values of firm characteristics for negative and positive gap firms are based on industry and propensity score matching. Estimates of probit regressions for non-regulated firms where the dependent variable takes a value of one for positive gap firms. SGROWTH (sales growth), R\&D/SALES, FOREIGN SALES/SALES are two-year averages and are winsorized at 1\% and 99\%; SIZE (natural log of total assets), CASH/ASSETS, CAPEX/ASSETS, PPE/SALES, EBIT/SALES, DEBT/ASSETS, CLOSELY HELD, $A D R$ dummy, GDPPC (GDP per capita) and MarketCap/GDP are included. Common Law dummy equals one for a country with common law; the Rule of Law and the Anti-Director indices are from LLSV (1998) and DLLS (2006), respectively; the Anti-SelfDealing Index is also from DLLS (2006). p-values obtained from chi-squared tests for differences in medians are in parentheses for the descriptive statistics. Probit regressions include industry dummies and standard errors are corrected for country-level clustering (tstatistics are in parentheses). ${ }^{*}, * *, * * *$ reflects significance at $10 \%, 5 \%$ and $1 \%$.levels.

\begin{tabular}{|c|c|c|c|c|c|c|}
\hline & \multicolumn{3}{|c|}{\begin{tabular}{|c|} 
Descriptive Statistics \\
\end{tabular}} & \multirow{2}{*}{\multicolumn{3}{|c|}{$\begin{array}{c}\text { Probit Regressions } \\
\text { LHS: Positive Gap Dummy } \\
(N=1555)\end{array}$}} \\
\hline & $\begin{array}{l}\text { Negative Gov. Gap } \\
\# \text { of Firms. }=1393\end{array}$ & $\begin{array}{c}\text { Positive Gov. Gap } \\
\text { \# of Firms }=206\end{array}$ & $\begin{array}{l}\text { Difference between } \\
\text { Neg. and Pos. Gap }\end{array}$ & & & \\
\hline$Q$ & 1.28 & 1.57 & $\begin{array}{c}-0.29 \\
(0.00)^{* * *}\end{array}$ & & & \\
\hline MKT. CAP (\$ millions) & 1565.25 & 1173.45 & $\begin{array}{c}391.80 \\
(0.01)^{* * *}\end{array}$ & & & \\
\hline GOV & 0.46 & 0.64 & $\begin{array}{c}-0.18 \\
(0.00)^{* * *}\end{array}$ & & & \\
\hline SIZE, assets (\$ millions) & 2197.94 & 1187.47 & $\begin{array}{l}1010.47 \\
(0.00)^{* * *}\end{array}$ & $\begin{array}{l}-0.007 \\
(1.19)\end{array}$ & $\begin{array}{c}-0.011 \\
(2.03)^{* *}\end{array}$ & $\begin{array}{c}-0.022 \\
(4.99)^{* * *}\end{array}$ \\
\hline SGROWTH & 0.05 & 0.08 & $\begin{array}{c}-0.03 \\
(0.00)^{* * *}\end{array}$ & $\begin{array}{l}0.010 \\
(0.40)\end{array}$ & $\begin{array}{l}0.019 \\
(1.00)\end{array}$ & $\begin{array}{c}0.041 \\
(2.60)^{* * *}\end{array}$ \\
\hline$P P E / S A L E S$ & 0.00 & 0.00 & $\begin{array}{c}0.00 \\
(0.38)\end{array}$ & $\begin{array}{l}0.001 \\
(0.55)\end{array}$ & $\begin{array}{l}0.001 \\
(0.36)\end{array}$ & $\begin{array}{l}0.002 \\
(0.89)\end{array}$ \\
\hline$R \& D / S A L E S$ & 0.24 & 0.35 & $\begin{array}{c}-0.10 \\
(0.00)^{* * *}\end{array}$ & $\begin{array}{c}0.201 \\
(2.72)^{* * *}\end{array}$ & $\begin{array}{c}0.215 \\
(2.93)^{* * *}\end{array}$ & $\begin{array}{c}0.220 \\
(2.44)^{* *}\end{array}$ \\
\hline FOREIGN SALES/SALES & 0.11 & 0.06 & $\begin{array}{c}0.05 \\
(0.29)\end{array}$ & $\begin{array}{l}0.023 \\
(0.87)\end{array}$ & $\begin{array}{l}0.025 \\
(0.90)\end{array}$ & $\begin{array}{l}0.036 \\
(1.11)\end{array}$ \\
\hline CASH/ASSSETS & 0.03 & 0.04 & $\begin{array}{c}-0.01 \\
(0.00)^{* * *}\end{array}$ & $\begin{array}{c}-0.209 \\
(5.05) * * *\end{array}$ & $\begin{array}{c}-0.223 \\
(4.88)^{* * *}\end{array}$ & $\begin{array}{c}-0.294 \\
(5.00)^{* * *}\end{array}$ \\
\hline CAPEX/ASSSETS & 0.26 & 0.24 & $\begin{array}{c}0.02 \\
(0.05)^{* *}\end{array}$ & $\begin{array}{l}-0.038 \\
(0.63)\end{array}$ & $\begin{array}{l}-0.029 \\
(0.42)\end{array}$ & $\begin{array}{l}-0.056 \\
(0.71)\end{array}$ \\
\hline EBIT/SALES & 0.08 & 0.09 & $\begin{array}{l}-0.01 \\
(0.13)\end{array}$ & $\begin{array}{l}0.001 \\
(0.83)\end{array}$ & $\begin{array}{l}0.000 \\
(0.16)\end{array}$ & $\begin{array}{l}0.001 \\
(0.35)\end{array}$ \\
\hline DEBT/ASSETS & 0.21 & 0.24 & $\begin{array}{c}-0.04 \\
(0.05)^{* *}\end{array}$ & $\begin{array}{l}0.010 \\
(0.29)\end{array}$ & $\begin{array}{l}0.019 \\
(0.64)\end{array}$ & $\begin{array}{l}0.014 \\
(0.35)\end{array}$ \\
\hline CLOSELY HELD & 0.40 & 0.48 & $\begin{array}{c}-0.08 \\
(0.00)^{* * *}\end{array}$ & $\begin{array}{l}-0.045 \\
(1.14)\end{array}$ & $\begin{array}{l}-0.042 \\
(1.34)\end{array}$ & $\begin{array}{l}-0.008 \\
(0.19)\end{array}$ \\
\hline$A D R$ & 0.00 & 0.00 & $\begin{array}{c}0.00 \\
(0.01)^{* * *}\end{array}$ & $\begin{array}{l}0.018 \\
(1.12)\end{array}$ & $\begin{array}{l}0.043 \\
(1.50)\end{array}$ & $\begin{array}{l}0.070 \\
(1.59)\end{array}$ \\
\hline$G D P P C$ & 10.19 & 10.19 & $\begin{array}{c}0.00 \\
(0.000)\end{array}$ & $\begin{array}{l}0.013 \\
(0.15)\end{array}$ & $\begin{array}{l}-0.066 \\
(0.69)\end{array}$ & $\begin{array}{l}-0.096 \\
(0.90)\end{array}$ \\
\hline MarketCap/GDP & 94.88 & 131.53 & $\begin{array}{c}-36.65 \\
(0.00)^{* * *}\end{array}$ & $\begin{array}{c}-0.000 \\
(2.15)^{* *}\end{array}$ & $\begin{array}{l}-0.000 \\
(1.59)\end{array}$ & $\begin{array}{l}-0.000 \\
(1.18)\end{array}$ \\
\hline Common Law & 0 & 1 & $\begin{array}{c}-1 \\
(0.00)^{* * *}\end{array}$ & $\begin{array}{c}0.235 \\
(4.29)^{* * *}\end{array}$ & & \\
\hline Rule of Law*Anti-Director & 31.43 & 40.00 & $\begin{array}{c}-8.57 \\
(0.00)^{* * *}\end{array}$ & & $\begin{array}{c}0.013 \\
(5.14)^{* * *}\end{array}$ & \\
\hline Anti-Self Dealing Index & 0.48 & 0.86 & $\begin{array}{c}-0.38 \\
(0.00)^{* * *}\end{array}$ & & & $\begin{array}{c}0.224 \\
(3.25)^{* * *}\end{array}$ \\
\hline Adj. R-squared & & & & 0.26 & 0.23 & 0.18 \\
\hline
\end{tabular}




\section{Table 5}

\section{Tobin's q, Firm Governance, and Firm Characteristics}

The table shows estimates of regressions of firm value (Tobin's q, winsorized at $1 \%$ and $99 \%$ ) on differences in governance between a foreign firm and a matched U.S. firm based on industry and propensity scores obtained from a probit analysis. GOV_US is the governance index for the matched U.S. firm. NEGATIVE GAP and POSITIVE GAP are the governance gap of a firm from its matching U.S. counterpart if negative and if positive, respectively. GOV. GAP includes both negative and positive gap. SGROWTH (sales growth), R\&D/SALES, FOREIGN SALES/SALES are two-year averages and winsorized at $1 \%$ and 99\%; SIZE (natural log of total assets), CASH/ASSETS, CAPEX/ASSETS, PPE/SALES, EBIT/SALES and DEBT/ASSETS are included for control. All regressions include industry and country dummies (except for the two-stage least squares regressions which do not have country dummies) and standard errors are corrected for clustering of observations at the country level (t-statistics are in parentheses). In regressions (3) and (6), GOV GAP is instrumented with the average GOV GAP of the other firms in the same industry in the same country. F-statistics test the hypothesis that the corresponding coefficients are equal to each other. ${ }^{*},{ }^{* *},{ }^{* * *}$ reflects significance at the $10 \%, 5 \%$ and $1 \%$ levels.

\begin{tabular}{|c|c|c|c|c|c|c|}
\hline & $(1)$ & $(2)$ & (3) & (4) & (5) & (6) \\
\hline \multirow[t]{2}{*}{ GOV_US } & 2.023 & 2.031 & 1.777 & 0.959 & 0.967 & 0.806 \\
\hline & $(4.48) * * *$ & $(4.55)^{* * *}$ & $(2.85) * * *$ & $(2.15)^{* *}$ & $(2.23)^{* *}$ & (1.27) \\
\hline \multirow[t]{2}{*}{ GOV. GAP } & 1.307 & & 1.114 & 1.235 & & 1.046 \\
\hline & $(3.91)^{* * *}$ & & $(1.80)^{*}$ & $(3.70) * * *$ & & $(1.82)^{*}$ \\
\hline \multirow[t]{2}{*}{ NEGATIVE GAP } & & 1.358 & & & 1.283 & \\
\hline & & $(3.53) * * *$ & & & $(3.51)^{* * *}$ & \\
\hline \multirow[t]{2}{*}{ POSITIVE GAP } & & 1.063 & & & 1.009 & \\
\hline & & $(0.98)$ & & & $(1.10)$ & \\
\hline \multirow[t]{2}{*}{ SIZE } & -0.161 & -0.161 & -0.171 & -0.085 & -0.085 & -0.107 \\
\hline & $(5.92)^{* * *}$ & $(5.92) * * *$ & $(8.71)^{* * *}$ & $(3.37) * * *$ & $(3.36)^{* * *}$ & $(5.78)^{* * *}$ \\
\hline \multirow[t]{2}{*}{ SGROWTH } & & & & 0.246 & 0.246 & 0.272 \\
\hline & & & & $(1.46)$ & (1.46) & $(1.48)$ \\
\hline \multirow[t]{2}{*}{$R \& D / S A L E S$} & & & & 2.179 & 2.172 & 2.196 \\
\hline & & & & $(2.94)^{* * *}$ & $(2.85)^{* * *}$ & $(2.75)^{* *}$ \\
\hline \multicolumn{7}{|l|}{ FOREIGN } \\
\hline \multirow[t]{2}{*}{ SALES/SALES } & & & & 0.120 & 0.119 & 0.179 \\
\hline & & & & (1.34) & (1.29) & $(1.91)^{*}$ \\
\hline \multirow[t]{2}{*}{ CASH/ASSETS } & & & & 2.353 & 2.355 & 2.168 \\
\hline & & & & $(7.34)^{* * *}$ & $(7.31)^{* * *}$ & $(7.52)^{* * *}$ \\
\hline \multirow[t]{2}{*}{ CAPEX/ASSETS } & & & & 3.057 & 3.060 & 3.567 \\
\hline & & & & $(3.83) * * *$ & $(3.84)^{* * *}$ & $(4.69)^{* * *}$ \\
\hline \multirow[t]{2}{*}{ PPE/Sales } & & & & -0.010 & -0.010 & -0.015 \\
\hline & & & & $(1.16)$ & $(1.17)$ & $(1.87)^{*}$ \\
\hline \multirow[t]{2}{*}{ EBIT/SALES } & & & & 0.027 & 0.027 & 0.027 \\
\hline & & & & $(8.64)^{* * *}$ & $(8.45)^{* * *}$ & $(6.98) * * *$ \\
\hline \multirow[t]{2}{*}{ DEBT/ASSETS } & & & & 0.062 & 0.062 & 0.173 \\
\hline & & & & $(0.23)$ & $(0.23)$ & $(0.71)$ \\
\hline \multirow[t]{2}{*}{ Constant } & 2.844 & 2.850 & 3.106 & 1.658 & 1.663 & 1.972 \\
\hline & $(7.35)^{* * *}$ & $(7.35)^{* * *}$ & $(5.35)^{* * *}$ & $(4.97)^{* * *}$ & $(4.98)^{* * *}$ & $(4.14)^{* * *}$ \\
\hline Observations & 1599 & 1599 & 1527 & 1599 & 1599 & 1527 \\
\hline Adj R-Squared & 0.24 & 0.24 & 0.24 & 0.37 & 0.37 & 0.34 \\
\hline
\end{tabular}


Table 6

\section{Firm Value, Governance, and Country Characteristics}

The table shows estimates of regressions of firm value (Tobin's q, winsorized at $1 \%$ and $99 \%$ ) on differences in governance between a foreign firm and a matched U.S. firm based on industry and propensity scores obtained from a probit analysis. GOV US is the governance index for the matched U.S. firm. NEGATIVE GAP and POSITIVE GAP are the governance gap of a firm from its matching U.S. counterpart if negative and if positive, respectively. GOV. GAP includes both negative and positive gap. SGROWTH (sales growth), R\&D/SALES, FOREIGN SALES/SALES are two-year averages and winsorized at 1\% and 99\%; SIZE (natural log of total assets), CASH/ASSETS, CAPEX/ASSETS, PPE/SALES, EBIT/SALES and DEBT/ASSETS are included for control. CLOSELY $H E L D$ is the percentage of shares closely held and $A D R$ dummy equals one if for firms cross-listed in the U.S. Common Law dummy equals one for a country with common law; the Rule of Law and the Anti-Director indices are from LLSV (1998) and DLLS (2006), respectively; the Anti-Self-Dealing Index is also from DLLS (2006).All regressions include industry fixed effects and the first three regressions also include country fixed effects. Standard errors are corrected for clustering of observations at the country level (tstatistics are in parentheses). ${ }^{*}, * *, * * *$ reflects significance at the $10 \%, 5 \%$ and $1 \%$ levels. 


\begin{tabular}{|c|c|c|c|c|c|c|c|c|c|}
\hline & $(1)$ & $(2)$ & (3) & $(4)$ & $(5)$ & $(6)$ & $(7)$ & $(8)$ & $(9)$ \\
\hline$G O V \_U S$ & $\begin{array}{c}0.911 \\
(2.08)^{* *}\end{array}$ & $\begin{array}{c}0.910 \\
(2.13)^{* *}\end{array}$ & $\begin{array}{l}-0.358 \\
(1.72)^{*}\end{array}$ & $\begin{array}{l}0.520 \\
(1.11)\end{array}$ & $\begin{array}{l}0.562 \\
(1.37)\end{array}$ & $\begin{array}{l}0.224 \\
(0.41)\end{array}$ & $\begin{array}{l}0.267 \\
(0.55)\end{array}$ & $\begin{array}{l}0.386 \\
(0.80)\end{array}$ & $\begin{array}{l}0.437 \\
(1.08)\end{array}$ \\
\hline$G O V G A P$ & $\begin{array}{c}1.279 \\
(3.76)^{* * *}\end{array}$ & & & $\begin{array}{c}0.872 \\
(2.48)^{* *}\end{array}$ & & $\begin{array}{l}0.542 \\
(1.34)\end{array}$ & & $\begin{array}{c}0.727 \\
(1.98)^{*}\end{array}$ & \\
\hline NEGATIVE GAP & & $\begin{array}{c}1.273 \\
(3.55)^{* * *}\end{array}$ & & & $\begin{array}{c}1.031 \\
(3.56)^{* * *}\end{array}$ & & $\begin{array}{c}0.694 \\
(2.27)^{* *}\end{array}$ & & $\begin{array}{c}0.911 \\
(3.91)^{* * *}\end{array}$ \\
\hline POSITIVE GAP & & $\begin{array}{l}1.310 \\
(1.23)\end{array}$ & & & $\begin{array}{c}0.243 \\
(0.23)\end{array}$ & & $\begin{array}{r}-0.025 \\
(0.02)\end{array}$ & & $\begin{array}{l}0.021 \\
(0.02)\end{array}$ \\
\hline SIZE & $\begin{array}{c}-0.101 \\
(3.27)^{* * *}\end{array}$ & $\begin{array}{c}-0.101 \\
(3.24)^{* * *}\end{array}$ & $\begin{array}{c}-0.092 \\
(3.33)^{* * *}\end{array}$ & $\begin{array}{c}-0.108 \\
(4.15)^{* * *}\end{array}$ & $\begin{array}{c}-0.107 \\
(4.09)^{* * * *}\end{array}$ & $\begin{array}{c}-0.094 \\
(3.42)^{* * *}\end{array}$ & $\begin{array}{c}-0.093 \\
(3.39)^{* * *}\end{array}$ & $\begin{array}{c}-0.105 \\
(4.33)^{* * *}\end{array}$ & $\begin{array}{c}-0.105 \\
(4.31)^{* * *}\end{array}$ \\
\hline SGROWTH & $\begin{array}{c}0.278 \\
(1.63)\end{array}$ & $\begin{array}{l}0.278 \\
(1.62)\end{array}$ & $\begin{array}{l}0.273 \\
(1.61)\end{array}$ & $\begin{array}{l}0.283 \\
(1.68)\end{array}$ & $\begin{array}{l}0.286 \\
(1.71)\end{array}$ & $\begin{array}{l}0.263 \\
(1.52)\end{array}$ & $\begin{array}{c}0.266 \\
(1.55)\end{array}$ & $\begin{array}{l}0.278 \\
(1.64)\end{array}$ & $\begin{array}{l}0.282 \\
(1.68)\end{array}$ \\
\hline PPE/SALES & $\begin{array}{l}-0.010 \\
(1.08)\end{array}$ & $\begin{array}{l}-0.010 \\
(1.09)\end{array}$ & $\begin{array}{l}-0.010 \\
(1.08)\end{array}$ & $\begin{array}{l}-0.014 \\
(1.75)^{*}\end{array}$ & $\begin{array}{l}-0.015 \\
(1.82)^{*}\end{array}$ & $\begin{array}{c}-0.016 \\
(1.99)^{*}\end{array}$ & $\begin{array}{l}-0.016 \\
(2.05)^{*}\end{array}$ & $\begin{array}{l}-0.015 \\
(1.79)^{*}\end{array}$ & $\begin{array}{l}-0.015 \\
(1.84)^{*}\end{array}$ \\
\hline$R \& D / S A L E S$ & $\begin{array}{c}2.023 \\
(2.79)^{* *}\end{array}$ & $\begin{array}{c}2.024 \\
(2.74)^{* *}\end{array}$ & $\begin{array}{c}2.027 \\
(2.75)^{* *}\end{array}$ & $\begin{array}{c}2.195 \\
(3.48)^{* * *}\end{array}$ & $\begin{array}{c}2.161 \\
(3.23)^{* * *}\end{array}$ & $\begin{array}{c}2.192 \\
(3.44)^{* * *}\end{array}$ & $\begin{array}{c}2.162 \\
(3.20)^{* * *}\end{array}$ & $\begin{array}{c}2.210 \\
(3.50)^{* * *}\end{array}$ & $\begin{array}{c}2.173 \\
(3.24)^{* * *}\end{array}$ \\
\hline FOREIGN SALES/SALES & $\begin{array}{c}0.082 \\
(0.89)\end{array}$ & $\begin{array}{c}0.082 \\
(0.86)\end{array}$ & $\begin{array}{l}0.094 \\
(0.97)\end{array}$ & $\begin{array}{l}0.070 \\
(0.72)\end{array}$ & $\begin{array}{l}0.066 \\
(0.67)\end{array}$ & $\begin{array}{l}0.080 \\
(0.80)\end{array}$ & $\begin{array}{l}0.077 \\
(0.75)\end{array}$ & $\begin{array}{l}0.064 \\
(0.65)\end{array}$ & $\begin{array}{l}0.059 \\
(0.58)\end{array}$ \\
\hline CASH/ASSETS & $\begin{array}{c}2.294 \\
(6.89)^{* * *}\end{array}$ & $\begin{array}{c}2.294 \\
(6.82)^{* * *}\end{array}$ & $\begin{array}{c}2.299 \\
(6.75)^{* * *}\end{array}$ & $\begin{array}{c}2.229 \\
(6.88)^{* * *}\end{array}$ & $\begin{array}{c}2.235 \\
(6.85)^{* * *}\end{array}$ & $\begin{array}{c}2.271 \\
(6.90)^{* * *}\end{array}$ & $\begin{array}{c}2.276 \\
(6.86)^{* * *}\end{array}$ & $\begin{array}{c}2.233 \\
(6.92)^{* * *}\end{array}$ & $\begin{array}{c}2.238 \\
(6.90)^{* * *}\end{array}$ \\
\hline CAPEX/ASSETS & $\begin{array}{c}3.051 \\
(3.90)^{* * *}\end{array}$ & $\begin{array}{c}3.050 \\
(3.90)^{* * *}\end{array}$ & $\begin{array}{c}3.040 \\
(3.82)^{* * *}\end{array}$ & $\begin{array}{c}2.967 \\
(3.58)^{* * *}\end{array}$ & $\begin{array}{c}2.977 \\
(3.60)^{* * *}\end{array}$ & $\begin{array}{c}2.991 \\
(3.70)^{* * *}\end{array}$ & $\begin{array}{c}2.999 \\
(3.71)^{* * *}\end{array}$ & $\begin{array}{c}2.966 \\
(3.60)^{* * *}\end{array}$ & $\begin{array}{c}2.976 \\
(3.62)^{* * *}\end{array}$ \\
\hline EBIT/SALES & $\begin{array}{c}0.026 \\
(8.53)^{* * *}\end{array}$ & $\begin{array}{c}0.026 \\
(8.36)^{* * * *}\end{array}$ & $\begin{array}{c}0.027 \\
(8.63)^{* * *}\end{array}$ & $\begin{array}{c}0.027 \\
(7.66)^{* * * *}\end{array}$ & $\begin{array}{c}0.027 \\
(7.65)^{* * * *}\end{array}$ & $\begin{array}{c}0.028 \\
(7.59)^{* * *}\end{array}$ & $\begin{array}{c}0.028 \\
(7.59)^{* * *}\end{array}$ & $\begin{array}{c}0.027 \\
(7.79)^{* * *}\end{array}$ & $\begin{array}{c}0.027 \\
(7.74)^{* * *}\end{array}$ \\
\hline DEBT/ASSETS & $\begin{array}{l}0.072 \\
(0.27)\end{array}$ & $\begin{array}{l}0.072 \\
(0.27)\end{array}$ & $\begin{array}{l}0.081 \\
(0.31)\end{array}$ & $\begin{array}{l}0.093 \\
(0.36)\end{array}$ & $\begin{array}{l}0.092 \\
(0.36)\end{array}$ & $\begin{array}{l}0.086 \\
(0.33)\end{array}$ & $\begin{array}{l}0.086 \\
(0.33)\end{array}$ & $\begin{array}{l}0.097 \\
(0.38)\end{array}$ & $\begin{array}{l}0.097 \\
(0.38)\end{array}$ \\
\hline CLOSELY HELD & $\begin{array}{c}0.217 \\
(1.76)^{*}\end{array}$ & $\begin{array}{c}0.217 \\
(1.75)^{*}\end{array}$ & $\begin{array}{l}0.181 \\
(1.36)\end{array}$ & $\begin{array}{l}0.202 \\
(1.45)\end{array}$ & $\begin{array}{l}0.201 \\
(1.44)\end{array}$ & $\begin{array}{l}0.137 \\
(1.03)\end{array}$ & $\begin{array}{l}0.136 \\
(1.02)\end{array}$ & $\begin{array}{l}0.205 \\
(1.48)\end{array}$ & $\begin{array}{l}0.205 \\
(1.47)\end{array}$ \\
\hline$A D R$ & $\begin{array}{c}0.172 \\
(2.58)^{* *}\end{array}$ & $\begin{array}{c}0.172 \\
(2.57)^{* *}\end{array}$ & $\begin{array}{c}0.181 \\
(2.87)^{* * *}\end{array}$ & $\begin{array}{c}0.151 \\
(2.66)^{* *}\end{array}$ & $\begin{array}{c}0.151 \\
(2.67)^{* *}\end{array}$ & $\begin{array}{c}0.134 \\
(2.20)^{* *}\end{array}$ & $\begin{array}{c}0.134 \\
(2.22)^{* *}\end{array}$ & $\begin{array}{c}0.143 \\
(2.57)^{* *}\end{array}$ & $\begin{array}{c}0.144 \\
(2.61)^{* *}\end{array}$ \\
\hline$G D P P C$ & & & & $\begin{array}{c}-0.439 \\
(3.72)^{* * *}\end{array}$ & $\begin{array}{c}-0.438 \\
(3.81)^{* * *}\end{array}$ & $\begin{array}{c}-0.413 \\
(3.17)^{* * *}\end{array}$ & $\begin{array}{c}-0.410 \\
(3.21)^{* * *}\end{array}$ & $\begin{array}{c}-0.402 \\
(3.37)^{* * *}\end{array}$ & $\begin{array}{c}-0.400 \\
(3.44) * * *\end{array}$ \\
\hline Market $C A P / G D P$ & & & & $\begin{array}{l}0.000 \\
(0.08)\end{array}$ & $\begin{array}{l}0.000 \\
(0.06)\end{array}$ & $\begin{array}{c}-0.000 \\
(1.02)\end{array}$ & $\begin{array}{r}-0.000 \\
(1.03)\end{array}$ & $\begin{array}{r}-0.000 \\
(0.04)\end{array}$ & $\begin{array}{c}-0.000 \\
(0.02)\end{array}$ \\
\hline COMMON LAW & & & & $\begin{array}{l}-0.126 \\
(1.38)\end{array}$ & $\begin{array}{l}-0.127 \\
(1.40)\end{array}$ & & & & \\
\hline Rule of Law*Anti Director & & & & & & $\begin{array}{l}0.002 \\
(0.38)\end{array}$ & $\begin{array}{l}0.002 \\
(0.33)\end{array}$ & & \\
\hline Anti-Self-Dealing & & & & & & & & $\begin{array}{l}-0.194 \\
(1.28)\end{array}$ & $\begin{array}{l}-0.206 \\
(1.40)\end{array}$ \\
\hline Constant & $\begin{array}{c}1.840 \\
(3.95)^{* * *}\end{array}$ & $\begin{array}{c}1.840 \\
(3.96)^{* * *}\end{array}$ & $\begin{array}{c}2.339 \\
(4.95)^{* * *}\end{array}$ & $\begin{array}{c}6.691 \\
(4.72)^{* * *}\end{array}$ & $\begin{array}{c}6.673 \\
(4.80)^{* * *}\end{array}$ & $\begin{array}{c}6.274 \\
(4.30)^{* * *}\end{array}$ & $\begin{array}{c}6.253 \\
(4.34)^{* * *}\end{array}$ & $\begin{array}{c}6.410 \\
(4.50)^{* * *}\end{array}$ & $\begin{array}{c}6.392 \\
(4.59)^{* * *}\end{array}$ \\
\hline Adj. R-squared & 0.37 & 0.37 & 0.37 & 0.36 & 0.36 & 0.36 & 0.36 & 0.36 & 0.36 \\
\hline Number of Observations & 1581 & 1581 & 1584 & 1581 & 1581 & 1581 & 1581 & 1581 & 1581 \\
\hline
\end{tabular}


Table 7

\section{Individual Attributes by Country and Differences from the U.S.}

The table represents the percentage of firms in each country that meets or exceeds the minimum satisfactory threshold for each governance attribute. The seven attributes are: Board Independence: board is controlled by more than $50 \%$ independent outside directors; Board Size: board size is at greater than five but less than 16; Chairman/CEO Separation: chairman and CEO are separated or there is a lead director; Board Structure: annually elected board (no staggered board); Audit Committee Independence: audit committee comprised solely of independent outsiders; Auditor Ratification: auditors ratified at most recent annual meeting; and Stock Classes: only single class, common stock (no dual class). Italics are used if the mean difference in the attribute for a country with the U.S. is negative and is statistically significant at the $5 \%$ level. If the difference is positive and significant, it is shown in bold. Significance is not reported if zero percent or 100 percent of firms satisfy an attribute in a country.

\begin{tabular}{lccccccc}
\hline Country & $\begin{array}{c}\text { Board } \\
\text { Independ. }\end{array}$ & Board Size & $\begin{array}{c}\text { Chairman/CEO } \\
\text { Separation }\end{array}$ & $\begin{array}{c}\text { Board } \\
\text { Structure }\end{array}$ & $\begin{array}{c}\text { Audit Comm. } \\
\text { Independ. }\end{array}$ & $\begin{array}{c}\text { Auditor } \\
\text { Ratification }\end{array}$ & $\begin{array}{c}\text { Stock } \\
\text { Classes }\end{array}$ \\
\hline Australia & $39 \%$ & $\mathbf{8 8 \%}$ & $\mathbf{9 7 \%}$ & $1 \%$ & $24 \%$ & $12 \%$ & $\mathbf{9 8 \%}$ \\
Austria & $0 \%$ & $67 \%$ & $100 \%$ & $0 \%$ & $0 \%$ & $100 \%$ & $100 \%$ \\
Belgium & $25 \%$ & $85 \%$ & $60 \%$ & $0 \%$ & $20 \%$ & $5 \%$ & $95 \%$ \\
Canada & $91 \%$ & $\mathbf{9 4 \%}$ & $\mathbf{9 5 \%}$ & $\mathbf{9 8 \%}$ & $91 \%$ & $\mathbf{9 8 \%}$ & $68 \%$ \\
Denmark & $71 \%$ & $79 \%$ & $100 \%$ & $64 \%$ & $7 \%$ & $100 \%$ & $57 \%$ \\
Finland & $64 \%$ & $80 \%$ & $100 \%$ & $\mathbf{8 4 \%}$ & $40 \%$ & $100 \%$ & $68 \%$ \\
France & $28 \%$ & $78 \%$ & $49 \%$ & $2 \%$ & $22 \%$ & $35 \%$ & $38 \%$ \\
Germany & $40 \%$ & $82 \%$ & $100 \%$ & $0 \%$ & $3 \%$ & $100 \%$ & $100 \%$ \\
Greece & $3 \%$ & $90 \%$ & $\mathbf{9 0 \%}$ & $3 \%$ & $7 \%$ & $\mathbf{9 7 \%}$ & $100 \%$ \\
Hong Kong & $8 \%$ & $\mathbf{8 9 \%}$ & $\mathbf{6 3 \%}$ & $4 \%$ & $56 \%$ & $100 \%$ & $100 \%$ \\
Ireland & $30 \%$ & $70 \%$ & $\mathbf{9 0 \%}$ & $0 \%$ & $20 \%$ & $\mathbf{9 0 \%}$ & $100 \%$ \\
Italy & $0 \%$ & $87 \%$ & $\mathbf{7 7 \%}$ & $0 \%$ & $3 \%$ & $33 \%$ & $100 \%$ \\
Japan & $1 \%$ & $80 \%$ & $0 \%$ & $42 \%$ & $2 \%$ & $2 \%$ & $100 \%$ \\
Netherlands & $83 \%$ & $73 \%$ & $\mathbf{9 8 \%}$ & $7 \%$ & $54 \%$ & $51 \%$ & $68 \%$ \\
New Zealand & $17 \%$ & $92 \%$ & $100 \%$ & $0 \%$ & $8 \%$ & $75 \%$ & $100 \%$ \\
Norway & $69 \%$ & $46 \%$ & $100 \%$ & $23 \%$ & $15 \%$ & $0 \%$ & $100 \%$ \\
Portugal & $43 \%$ & $100 \%$ & $43 \%$ & $0 \%$ & $0 \%$ & $14 \%$ & $86 \%$ \\
Singapore & $34 \%$ & $100 \%$ & $\mathbf{8 4 \%}$ & $0 \%$ & $40 \%$ & $100 \%$ & $100 \%$ \\
Spain & $6 \%$ & $80 \%$ & $\mathbf{6 0 \%}$ & $3 \%$ & $6 \%$ & $\mathbf{8 9 \%}$ & $100 \%$ \\
Sweden & $60 \%$ & $\mathbf{9 7 \%}$ & $100 \%$ & $100 \%$ & $17 \%$ & $14 \%$ & $66 \%$ \\
Switzerland & $75 \%$ & $81 \%$ & $\mathbf{9 8 \%}$ & $19 \%$ & $58 \%$ & $\mathbf{9 8 \%} \%$ & $\mathbf{9 8 \%}$ \\
U.K. & $32 \%$ & $\mathbf{9 0 \%}$ & $\mathbf{9 6 \%}$ & $8 \%$ & $68 \%$ & $\mathbf{9 9 \%}$ & $\mathbf{9 9 \%}$ \\
U.S.A. & $89 \%$ & $81 \%$ & $41 \%$ & $52 \%$ & $88 \%$ & $68 \%$ & $94 \%$ \\
\hline
\end{tabular}


Table 8

Individual Governance Attributes and Differences in Firm Value based on U.S. Matched-Firms

The table shows the relation between firm value (Tobin's q, which is winsorized at $1 \%$ and $99 \%$ ) and differences in individual governance attributes between a foreign firm and a matched U.S. firm based on industry and propensity scores obtained from a probit analysis. The seven attributes are: Board Independence: board is controlled by more than $50 \%$ independent outside directors; Board Size: board size is at greater than five but less than 16; Chairman/CEO Separation: chairman and CEO are separated or there is a lead director; Board Structure: annually elected board (no staggered board); Audit Committee Independence: audit committee comprised solely of independent outsiders; Auditor Ratification: auditors ratified at most recent annual meeting; and Stock Classes: only one class of common stock. Panel A reports results from seven different models that include one attribute at a time. Panel B reports results from one model that includes all seven attributes at the same time. ATTRIBUTE US is the governance attribute for the matched U.S. firm. NEGATIVE GAP and POSITIVE GAP are the governance gap of a firm from its matching U.S. counterpart if negative and if positive, respectively. The following control variables are included but their coefficients are not reported here: SIZE (natural log of total assets); $S G R O W T H$ (sales growth), $R \& D / S A L E S$, FOREIGN SALES/SALES are two-year averages and are winsorized at $1 \%$ and 99\%; CASH/ASSETS, CAPEX/ASSETS, PPE/SALES, EBIT/SALES and DEBT/ASSETS are also included. CLOSELY HELD is the percentage of shares closely held and $A D R$ dummy equals one if the firm is cross-listed in the U.S. All regressions include industry dummies, country $\mathrm{FE}$, and standard errors are corrected for country-level clustering. *, **, *** reflects significance at the $10 \%, 5 \%$ and $1 \%$ levels. Number of observations is 1,584 for each model.

\begin{tabular}{|c|c|c|c|c|c|c|c|}
\hline & $\begin{array}{c}\text { Board } \\
\text { Independ. }\end{array}$ & Board Size & $\begin{array}{l}\text { Chairman/ } \\
\text { CEO } \\
\text { Separation }\end{array}$ & $\begin{array}{c}\text { Board } \\
\text { Structure }\end{array}$ & $\begin{array}{c}\text { Audit } \\
\text { Comm. } \\
\text { Independ. }\end{array}$ & $\begin{array}{c}\text { Audit } \\
\text { Ratification }\end{array}$ & $\begin{array}{c}\text { Stock } \\
\text { Classes }\end{array}$ \\
\hline \multicolumn{8}{|c|}{ Panel A: Regressions Using Individual Governance Attributes } \\
\hline ATTRIBUTE_US & $\begin{array}{l}0.086 \\
(0.95)\end{array}$ & $\begin{array}{l}0.239 \\
(0.83)\end{array}$ & $\begin{array}{l}-0.012 \\
(0.21)\end{array}$ & $\begin{array}{l}0.028 \\
(0.26)\end{array}$ & $\begin{array}{l}0.004 \\
(0.02)\end{array}$ & $\begin{array}{c}0.097 \\
(1.67)^{*}\end{array}$ & $\begin{array}{l}0.095 \\
(0.52)\end{array}$ \\
\hline NEGATIVE GAP & $\begin{array}{c}0.225 \\
(6.27)^{* * *}\end{array}$ & $\begin{array}{l}-0.037 \\
(0.61)\end{array}$ & $\begin{array}{l}-0.039 \\
(0.66)\end{array}$ & $\begin{array}{l}-0.004 \\
(0.04)\end{array}$ & $\begin{array}{c}0.171 \\
(3.00)^{* * *}\end{array}$ & $\begin{array}{c}0.145 \\
(2.02) *\end{array}$ & $\begin{array}{l}0.084 \\
(1.22)\end{array}$ \\
\hline POSITIVE GAP & $\begin{array}{l}0.107 \\
(0.75)\end{array}$ & $\begin{array}{l}0.286 \\
(0.91)\end{array}$ & $\begin{array}{l}0.057 \\
(1.03)\end{array}$ & $\begin{array}{l}0.077 \\
(0.87)\end{array}$ & $\begin{array}{c}0.384 \\
(2.00)^{*}\end{array}$ & $\begin{array}{l}0.066 \\
(0.75)\end{array}$ & $\begin{array}{l}0.158 \\
(0.86)\end{array}$ \\
\hline Pseudo R-squared & 0.37 & 0.37 & 0.37 & 0.37 & 0.38 & 0.37 & 0.37 \\
\hline \multicolumn{8}{|c|}{ Panel B: Regression Using All Seven Attributes } \\
\hline ATTRIBUTE_US & $\begin{array}{l}0.069 \\
(0.74)\end{array}$ & $\begin{array}{l}0.191 \\
(0.68)\end{array}$ & $\begin{array}{l}0.014 \\
(0.16)\end{array}$ & $\begin{array}{l}-0.002 \\
(0.04)\end{array}$ & $\begin{array}{l}-0.053 \\
(0.31)\end{array}$ & $\begin{array}{c}0.133 \\
(2.23)^{* *}\end{array}$ & $\begin{array}{l}0.102 \\
(0.52)\end{array}$ \\
\hline NEGATIVE GAP & $\begin{array}{c}0.190 \\
(4.22)^{* * *}\end{array}$ & $\begin{array}{l}-0.038 \\
(0.61)\end{array}$ & $\begin{array}{l}-0.005 \\
(0.05)\end{array}$ & $\begin{array}{l}-0.032 \\
(0.62)\end{array}$ & $\begin{array}{c}0.111 \\
(1.76)^{*}\end{array}$ & $\begin{array}{c}0.171 \\
(2.08)^{* *}\end{array}$ & $\begin{array}{l}0.076 \\
(0.93)\end{array}$ \\
\hline POSITIVE GAP & $\begin{array}{l}0.040 \\
(0.34)\end{array}$ & $\begin{array}{l}0.246 \\
(0.80)\end{array}$ & $\begin{array}{l}0.058 \\
(0.72)\end{array}$ & $\begin{array}{l}0.046 \\
(0.96)\end{array}$ & $\begin{array}{c}0.340 \\
(1.79)^{*}\end{array}$ & $\begin{array}{l}0.098 \\
(1.05)\end{array}$ & $\begin{array}{l}0.146 \\
(0.74)\end{array}$ \\
\hline Pseudo R-squared & 0.37 & & & & & & \\
\hline
\end{tabular}


Table 9

Robustness Estimations

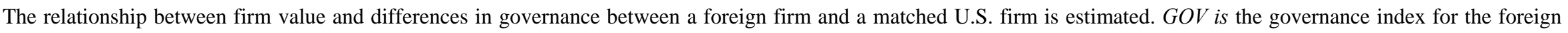

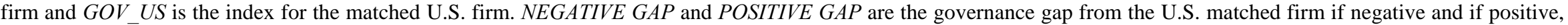

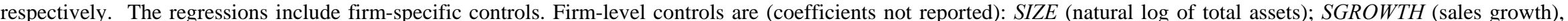

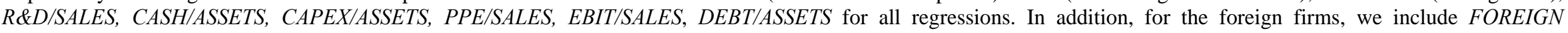
SALES/SALES, CLOSELY HELD, and the ADR dummy as controls. Median Industry $q$ is median $q$ for the firm's industry. All regressions, include industry dummies (except

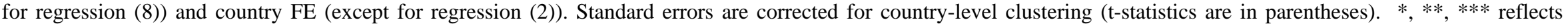
significance at the $10 \%, 5 \%$ and $1 \%$ levels.

\begin{tabular}{|c|c|c|c|c|c|c|c|c|}
\hline & (1) & $(2)$ & (3) & (4) & (5) & (6) & (7) & (8) \\
\hline & Foreign Firms & U.S. Firms & Foreign firms & $\begin{array}{c}\text { Size \& Ind } \\
\text { Matched }\end{array}$ & $\begin{array}{c}\text { Foreign } \\
\text { Ex. Japan } \\
\end{array}$ & $\begin{array}{l}\text { Foreign } \\
\text { Ex. U.K. }\end{array}$ & $\begin{array}{c}\text { Foreign } \\
\text { Ex. Canada } \\
\end{array}$ & $\begin{array}{c}\text { Median } \\
\text { Industry } q\end{array}$ \\
\hline$G O V$ & $\begin{array}{c}1.269 \\
(3.75)^{* * *}\end{array}$ & $\begin{array}{c}1.094 \\
(3.35)^{* * *}\end{array}$ & & & & & & \\
\hline $\mathrm{GOV}_{7} \mathrm{GAP}$ & & & $\begin{array}{c}0.515 \\
(2.64)^{* * *}\end{array}$ & & & & & \\
\hline GOV US & & & $\begin{array}{l}0.383 \\
(1.13)\end{array}$ & $\begin{array}{c}1.248 \\
(1.98)^{*}\end{array}$ & $\begin{array}{c}1.170 \\
(2.71)^{* *}\end{array}$ & $\begin{array}{l}0.595 \\
(1.18)\end{array}$ & $\begin{array}{c}0.904 \\
(1.91)^{*}\end{array}$ & $\begin{array}{c}0.874 \\
(2.16)^{* *}\end{array}$ \\
\hline NEGATIVE GAP & & & & $\begin{array}{c}1.162 \\
(3.10)^{* * *}\end{array}$ & $\begin{array}{c}1.578 \\
(4.53)^{* * *}\end{array}$ & $\begin{array}{c}1.184 \\
(2.17)^{* *}\end{array}$ & $\begin{array}{c}1.090 \\
(3.38)^{* * *}\end{array}$ & $\begin{array}{c}1.284 \\
(3.52)^{* * *}\end{array}$ \\
\hline POSITIVE GAP & & & & $\begin{array}{c}2.264 \\
(3.48)^{* * *}\end{array}$ & $\begin{array}{l}1.382 \\
(1.23)\end{array}$ & $\begin{array}{l}0.222 \\
(0.26)\end{array}$ & $\begin{array}{c}2.687 \\
(3.75)^{* * *}\end{array}$ & $\begin{array}{l}1.285 \\
(1.15)\end{array}$ \\
\hline Median Industry $Q$ & & & & & & & & $\begin{array}{c}0.606 \\
(5.38)^{* * *}\end{array}$ \\
\hline Adj. R-squared & 0.37 & 0.29 & 0.38 & 0.37 & 0.34 & 0.38 & 0.38 & 0.36 \\
\hline \# of Observations & 1584 & 2325 & 1584 & 1584 & 1104 & 1183 & 1473 & 1584 \\
\hline
\end{tabular}

